\title{
Oceanic bromoform emissions weighted by their ozone depletion potential
}

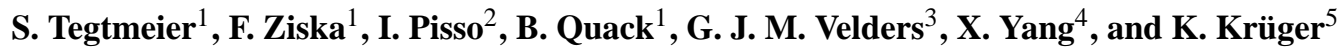 \\ ${ }^{1}$ GEOMAR Helmholtz Centre for Ocean Research Kiel, Kiel, Germany \\ ${ }^{2}$ Norwegian Institute for Air Research (NILU), Kjeller, Norway \\ ${ }^{3}$ National Institute for Public Health and the Environment, Bilthoven, the Netherlands \\ ${ }^{4}$ British Antarctic Survey, Cambridge, UK \\ ${ }^{5}$ University of Oslo, Oslo, Norway \\ Correspondence to: S. Tegtmeier (stegtmeier@geomar.de)
}

Received: 12 March 2015 - Published in Atmos. Chem. Phys. Discuss.: 26 May 2015

Revised: 17 November 2015 - Accepted: 27 November 2015 - Published: 10 December 2015

\begin{abstract}
At present, anthropogenic halogens and oceanic emissions of very short-lived substances (VSLSs) both contribute to the observed stratospheric ozone depletion. Emissions of the long-lived anthropogenic halogens have been reduced and are currently declining, whereas emissions of the biogenic VSLSs are expected to increase in future climate due to anthropogenic activities affecting oceanic production and emissions. Here, we introduce a new approach for assessing the impact of oceanic halocarbons on stratospheric ozone by calculating their ozone depletion potential (ODP)-weighted emissions. Seasonally and spatially dependent, global distributions are derived within a case-study framework for $\mathrm{CHBr}_{3}$ for the period 1999-2006. At present, ODP-weighted emissions of $\mathrm{CHBr}_{3}$ amount up to $50 \%$ of ODP-weighted anthropogenic emissions of CFC-11 and to $9 \%$ of all long-lived ozone depleting halogens. The ODPweighted emissions are large where strong oceanic emissions coincide with high-reaching convective activity and show pronounced peaks at the Equator and the coasts with largest contributions from the Maritime Continent and western Pacific Ocean. Variations of tropical convective activity lead to seasonal shifts in the spatial distribution of the trajectoryderived ODP with the updraught mass flux, used as a proxy for trajectory-derived ODP, explaining $71 \%$ of the variance of the ODP distribution. Future climate projections based on the RCP 8.5 scenario suggest a $31 \%$ increase of the ODPweighted $\mathrm{CHBr}_{3}$ emissions by 2100 compared to present values. This increase is related to a larger convective updraught mass flux in the upper troposphere and increasing emissions
\end{abstract}

in a future climate. However, at the same time, it is reduced by less effective bromine-related ozone depletion due to declining stratospheric chlorine concentrations. The comparison of the ODP-weighted emissions of short- and long-lived halocarbons provides a new concept for assessing the overall impact of oceanic halocarbon emissions on stratospheric ozone depletion for current conditions and future projections.

\section{Introduction}

The overall abundance of ozone-depleting substances in the atmosphere has been decreasing since the beginning of the 21 st century as a result of the successful implementation of the 1987 Montreal Protocol and its later adjustments and amendments (Carpenter and Reimann, 2014). In contrast to the long-lived halocarbons, the halogenated very shortlived substances (VSLSs) with chemical lifetimes of less than 6 months are not controlled by the Montreal Protocol and are even suggested to increase in the future (Hepach et al., 2014; Hossaini et al., 2015). Brominated VSLSs are known to have large natural sources; however, evidence has emerged that their oceanic production and emissions are enhanced through anthropogenic activities which are expected to increase in the future (Leedham et al., 2013; Ziska et al., 2015). At present, oceanic VSLSs provide a significant contribution to the stratospheric bromine budget (Carpenter and Reimann, 2014). In the future, the decline of anthropogenic chlorine and bromine will further increase the rel- 
ative impact of oceanic VSLSs on stratospheric chemistry. The amount of ozone loss for given bromine emission, however, is expected to decrease due to decreasing stratospheric chlorine concentrations and thus a less efficient $\mathrm{BrO} / \mathrm{ClO}$ ozone loss cycle (Yang et al., 2014). Furthermore, the impacts of climate change on surface emissions, troposphereto-stratosphere transport, stratospheric chemistry and residence time will change the role of VSLSs (Pyle et al., 2007; Hossaini et al., 2012). While stratospheric ozone depletion due to long-lived halocarbons is expected to level off and reverse (Austin and Butchart, 2003), assessing oceanic VSLSs and their impact on stratospheric ozone in a future changing climate remains a challenge.

Over the last years, there has been increasing evidence from observational (e.g., Dorf et al., 2006; Sioris et al., 2006) and modeling (e.g., Warwick et al., 2006; Liang et al., 2010; Tegtmeier et al., 2012) studies that VSLSs provide a significant contribution to stratospheric total bromine $\left(\mathrm{Br}_{y}\right)$. The current best-estimate range of 2-8 ppt (Carpenter and Reimann, 2014) includes observation-derived estimates of $2.9 \mathrm{ppt}$ (Sala et al., 2014) and model-derived estimates of 4 ppt (Hossaini et al., 2013), 4.5-6 ppt (Aschmann and Sinnhuber, 2013) and 7.7 ppt (Liang et al., 2014). Brominated VSLSs reduce ozone in the lower stratosphere with current estimates of a 3-11\% contribution to ozone depletion (Hossaini et al., 2015) or a 2-10\% contribution (Braesicke et al., 2013; Yang et al., 2014). Through the relatively large impact of VSLSs on ozone in the lower stratosphere, VSLSs contribute $-0.02 \mathrm{~W} \mathrm{~m}^{-2}$ to global radiative forcing (Hossaini et al., 2015) ( $\sim 6 \%$ of the $0.33 \mathrm{~W} \mathrm{~m}^{-2}$ from all halocarbons of ozone-depleting substances).

The most abundant bromine-containing VSLSs are dibromomethane $\left(\mathrm{CH}_{2} \mathrm{Br}_{2}\right)$ and bromoform $\left(\mathrm{CHBr}_{3}\right)$ with potentially important source regions in tropical, subtropical and shelf waters (Quack et al., 2007). The contribution of VSLSs to stratospheric bromine in form of organic source gases or inorganic product gases depends strongly on the efficiency of troposphere-to-stratosphere transport relative to the photochemical loss of the source gases and to the wet deposition of the product gases. Uncertainties in the contribution of VSLSs to stratospheric halogen loading mainly result from uncertainties in the emission inventories (e.g., Hossaini et al., 2013) and from uncertainties in the modeled transport and wet deposition processes (e.g., Schofield et al., 2011).

The relative contribution of individual halocarbons to stratospheric ozone depletion is often quantified by the ozone depletion potential (ODP) defined as the time-integrated ozone depletion resulting from a unit mass emission of that substance relative to the ozone depletion resulting from a unit mass emission of CFC-11 ( $\left.\mathrm{CCl}_{3} \mathrm{~F}\right)$ (Wuebbles, 1983). Independent of the total amount of the substance emitted, the ODP describes only the potential but not the actual damaging effect of the substance to the ozone layer, relative to that of CFC-11. The ODP, traditionally defined for anthropogenic long-lived halogens, is a well-established and ex- tensively used measure and plays an important role in the Montreal Protocol for control metrics and reporting of emissions. Some recent studies have applied the ODP concept to VSLSs (e.g., Brioude et al., 2010; Pisso et al., 2010), which have also natural sources. Depending on the meteorological conditions, only a fraction of the originally released VSLSs reaches the stratosphere. As a consequence, the ODP of a VSLS is not one number as for the long-lived halocarbons but needs to be quantified as a function of time and location of emission. ODPs of VSLSs have been estimated based on Eulerian (Wuebbles et al., 2001) and Lagrangian (Brioude et al., 2010; Pisso et al., 2010) studies, showing strong geographical and seasonal variations, in particular within the tropics. The studies demonstrated that the ODPs of VSLSs are to a large degree determined by the efficiency of vertical transport from the surface to the stratosphere and that uncertainties in the ODPs arise mainly from uncertainties associated with the representation of convection.

Combining the emission strength and the ozonedestroying capabilities of a substance in a meaningful way can be achieved by calculating the ODP-weighted emissions. For the long-lived halocarbons, global ODP-weighted emissions can be calculated as the product of two numbers, their mean global emissions and their ODPs (e.g., Velders et al., 2007; Ravishankara et al., 2009). For the VSLSs, however, the concept of ODP-weighted emissions has not yet been applied. To do so requires combining estimates of the emissions with the ODPs, both of which are highly variable in space and time. Among the brominated VSLSs, the calculation of $\mathrm{CHBr}_{3}$ ODP-weighted emissions is now possible, since global emission inventories (Ziska et al., 2013) and global ODP maps (Pisso et al., 2010) has become available. ODP-weighted emissions provide insight in where and when $\mathrm{CHBr}_{3}$ is emitted that impacts stratospheric ozone. Furthermore, in a globally averaged framework, the ODP-weighted emissions allow comparisons of the impact of past, present and future long- and short-lived halocarbon emissions. The ODP-weighted emissions for the anthropogenic component of the $\mathrm{CHBr}_{3}$ emission budget cannot be calculated, since no reliable estimates of anthropogenic contributions are available at the moment. The concept is introduced here for the available total emission inventory.

We compile ODP-weighted emissions of $\mathrm{CHBr}_{3}$ in form of the seasonal and annual mean distribution in order to assess the overall impact of oceanic $\mathrm{CHBr}_{3}$ emissions on stratospheric ozone. First, we introduce the new approach of calculating ODP-weighted VSLS emissions, taking into account the high spatial variability of oceanic emission and ODP fields (Sect. 2). Maps and global mean values of ODPweighted $\mathrm{CHBr}_{3}$ emissions for present-day conditions are given in Sect. 3. The method and application are introduced for $\mathrm{CHBr}_{3}$ within a case-study framework and can be applied to all VSLSs where emissions and ODP are available at a spatial resolution necessary to describe their variability. In Sect. 4, we demonstrate that ODP fields of short-lived gases 
can be estimated based on the convective mass flux from meteorological reanalysis data and develop a proxy for the ODP of $\mathrm{CHBr}_{3}$. We use this method to derive long-term time series of ODP-weighted $\mathrm{CHBr}_{3}$ emissions for 1979-2013 based on ERA-Interim data in Sect. 5. Model-derived ODP-weighted $\mathrm{CHBr}_{3}$ emissions for present conditions are introduced in Sect. 6. Based on model projections of climate scenarios, the future development of the ODP-weighted $\mathrm{CHBr}_{3}$ emissions is analyzed in Sect. 7. This approach provides a new tool for an assessment of future growing biogenic VSLSs and declining chlorine emissions in the form of a direct comparison of the global-averaged ODP-weighted emissions of short- and long-lived halocarbons.

\section{Data and methods}

\section{$2.1 \mathrm{CHBr}_{3}$ emissions}

The present-day global emission scenario from Ziska et al. (2013) is a bottom-up estimate of the oceanic $\mathrm{CHBr}_{3}$ fluxes. Emissions are estimated using global surface concentration maps generated from the atmospheric and oceanic in situ measurements of the HalOcAt (Halocarbons in the Ocean and Atmosphere) database project (https://halocat. geomar.de). The in situ measurements collected between 1989 and 2011 were classified based on physical and biogeochemical characteristics of the ocean and atmosphere and extrapolated to a global $1^{\circ} \times 1^{\circ}$ grid with the ordinary least square regression technique. Based on the concentration maps, the oceanic emissions were calculated with the transfer coefficient parameterization of Nightingale et al. (2000) adapted to $\mathrm{CHBr}_{3}$ (Quack and Wallace, 2003). The concentration maps represent climatological fields covering the time period 1989-2011. The emissions are calculated as a 6-hourly time series based on meteorological ERA-Interim data (Dee et al., 2011) for 1979-2013 under the assumption that the constant concentration maps can be applied to the complete time period (Ziska et al., 2013). Recent model studies showed that atmospheric $\mathrm{CHBr}_{3}$ derived from the Ziska et al. (2013) bottom-up emission inventory agrees better with tropical atmospheric measurements then the $\mathrm{CHBr}_{3}$ model estimates derived from top-down emission inventories (Hossaini et al., 2013).

Future emission estimates are calculated based on the present-day (1989-2011) climatological concentration maps and future estimates of global sea surface temperature, pressure, winds and salinity (Ziska et al., 2015). The meteorological parameters are model output from the Community Earth System Model version 1 - Community Atmospheric Model version 5 (CESM1-CAM5) (Neale et al., 2010) runs based on the Representative Concentration Pathway (RCP) 8.5 scenarios conducted within phase 5 of the Coupled Model Intercomparison Project (CMIP5) (Taylor et al., 2012). The CESM1-CAM5 model has been chosen since it provides model output for all the parameters required to calculate future VSLS emissions and future ODP estimates (Sect. 2.2). Comparisons have shown that the global emissions based on historical CESM1-CAM5 meteorological data agree well with emissions based on ERA-Interim fields (Ziska et al., 2015). For the time period 2006-2100, the global monthly mean emissions are calculated based on the monthly mean meteorological input parameters from CESM1-CAM5 and the fixed atmospheric and oceanic concentrations from Ziska et al. (2013) following the parameterization of the air-sea gas exchange coefficient from Nightingale et al. (2000). The future global $\mathrm{CHBr}_{3}$ emissions increase by about $30 \%$ until 2100 for the CESM1-CAM5 RCP 8.5 simulation. These derived changes of the future VSLS emissions are only driven by projected changes in the meteorological and marine surface parameters, in particular, by changes in surface wind and sea surface temperature. The respective contributions of wind and temperature changes to the future emission increase can vary strongly depending on the region (Ziska et al., 2015). The future emissions do not take into account possible changes of the oceanic concentrations, since no reliable estimates of future oceanic halocarbon production and loss processes exist so far.

\section{2 $\mathrm{CHBr}_{3}$ trajectory-derived ODP}

The ozone depletion potential is a measure of a substance's destructive effect to the ozone layer relative to the reference substance CFC-11 (Wuebbles, 1983). ODPs of long-lived halogen compounds can be calculated based on the change in total ozone per unit mass emission of this compound using atmospheric chemistry-transport models. Alternatively, the ODP of a long-lived species $X$ can be estimated by a semiempirical approach (Solomon et al., 1992):

$\mathrm{ODP}_{X}=\frac{M_{\mathrm{CFC}-11}}{M_{X}} \frac{\alpha n_{\mathrm{Br}}+n_{\mathrm{Cl}}}{3} \frac{\tau_{X}}{\tau_{\mathrm{CFC}-11}}$,

where $\tau$ is the global atmospheric lifetime, $M$ is the molecular weight, $n$ is the number of halogen atoms and $\alpha$ is the effectiveness of ozone loss by bromine relative to ozone loss by chlorine. In contrast to the long-lived halocarbons, for VSLSs the tropospheric transport timescale plays a dominant role for the calculation of their ODP and the concept of a global lifetime $\tau_{X}$ cannot be adapted. Therefore, the global lifetime needs to be replaced by an expression weighting the fraction of VSLSs reaching the tropopause and their subsequent residence time in the stratosphere.

Following a method previously developed specifically for VSLSs, the ODP of $\mathrm{CHBr}_{3}$ is calculated as a function of location and time of emission $\left(x_{\mathrm{e}}, t_{\mathrm{e}}\right)$ based on ERA-Interimdriven FLEXPART trajectories (Pisso et al., 2010). Based on the trajectory calculations, the fraction of VSLSs reaching the tropopause and the stratospheric residence time are derived. Owing to the different timescales and processes in the troposphere and stratosphere, the estimates are based 
on separate ensembles of trajectories quantifying the transport in both regions. The tropospheric trajectory ensembles are used to determine the fraction of VSLSs reaching the tropopause at different injection points $(y, s)$. The subsequent residence time in the stratosphere is quantified from stratospheric trajectory ensembles run for a longer time period (20 years). ODPs as a function of location and time of emission were obtained from Eq. (1) where the expression $\int_{t_{\mathrm{e}}}^{\infty} \int_{\Omega} \sigma r_{X}^{\Omega} T^{\text {strat }} \mathrm{d} y \mathrm{~d} s$ replaces $\tau_{X}$. This expression integrated in time $s$ starting at the emission time $t_{\mathrm{e}}$ and throughout the surface $\Omega$ (representing the tropopause) is estimated from the tropospheric and stratospheric trajectory ensembles. Tropospheric transport appears as the probability $\sigma\left(y, s ; x_{\mathrm{e}}, t_{\mathrm{e}}\right)$ of injection at $(y, s)$ in $\Omega$, while physicochemical processes in the troposphere appear as the injected proportion of total halogen emitted $r_{X}^{\Omega}\left(y, s ; x_{\mathrm{e}}, t_{\mathrm{e}}\right)$. Stratospheric transport is taken into account by $T^{\text {strat }}(y, s)$, which expresses the stratospheric residence time of a parcel injected at the tropopause at $(y, s)$. An ozone depletion efficiency factor of 60 is used for bromine (Sinnhuber et al., 2009). A more detailed derivation of the approximations and parameterizations including a discussion of the errors involved can be found in Pisso et al. (2010).

\section{3 $\mathrm{CHBr}_{3}$ mass-flux-derived ODP}

While present-day ODP estimates for VSLSs based on ERAInterim are available (e.g., Pisso et al., 2010), the trajectorybased method has not been applied to future model scenarios so far. Therefore, we attempt to determine an ODP proxy easily available from climate model output, which can be used to derive future estimates of the ODP fields. In general, the ODP of a VSLS as a function of time and location of emission is determined by tropospheric and stratospheric chemistry and transport processes. It has been shown, however, that the effect of spatial variations in the stratospheric residence time on the ODP is relatively weak (Pisso et al., 2010). We identify a pronounced relationship between the ODP of $\mathrm{CHBr}_{3}$ and deep convective activity, which demonstrates that for such short-lived substances the ODP variability is mostly determined by tropospheric transport processes. Based on the identified relationship we develop a proxy for the ODP of $\mathrm{CHBr}_{3}$ based on the ERA-Interim convective upward mass flux. For the available trajectory-derived ODP fields, we determine a linear fit $\left[a_{0}, a_{1}\right]$ with residual $\boldsymbol{r}$ in a least-square sense:

$\boldsymbol{y}=a_{0}+a_{1} \boldsymbol{x}+\boldsymbol{r}$.

The dependent variable $\boldsymbol{y}$ is the trajectory-based ODP prescribed as a vector of all available monthly mean ODP values comprising 26 months of data re-gridded to the ERA-Interim standard resolution of $1^{\circ} \times 1^{\circ}$. The independent variable $\boldsymbol{x}$ is a vector of the ERA-Interim monthly mean updraught mass flux between 250 and $80 \mathrm{hPa}$ with a $1^{\circ} \times 1^{\circ}$ resolution for the same months. The fit coefficients $\left[a_{0}, a_{1}\right]$ are used to calcu- late the ODP proxy $\hat{\boldsymbol{y}}$ :

$\hat{\boldsymbol{y}}=a_{0}+a_{1} \boldsymbol{x}$.

The fit scores a coefficient of determination of 0.71 conveying that our ODP proxy (called mass-flux-derived ODP from now on) explains $71 \%$ of the variance of the original trajectory-derived ODP fields for the time period 1999-2006. We find good agreement between the trajectory-derived and the mass-flux-derived ODP and ODP-weighted $\mathrm{CHBr}_{3}$ emissions (see Sects. 4 and 5 for details). In order to extend the ODP-weighted $\mathrm{CHBr}_{3}$ emissions beyond 1999 and 2006, we apply the linear fit function $\left[a_{0}, a_{1}\right]$ to the convective upward mass flux between 250 and $80 \mathrm{hPa}$ from ERA-Interim and from the CESM1-CAM5 runs. Thus, we estimate observational (1979-2013), model historical (1979-2005) and model future RCP 8.5 (2006-2100) mass-flux-derived-ODP fields.

The ODP of such short-lived substances as $\mathrm{CHBr}_{3}$ shows a weak dependence on the stratospheric residence time and thus on the latitude of the injection point at the tropopause (Pisso et al., 2010). Our method of deriving the ODP from the convective mass flux neglects the impact of spatial variations in the stratospheric residence time on the ODP. However, within the tropical belt, which is the main region of interest for our analysis with high ODP values and strong convective mass fluxes, the stratospheric residence time can be approximated by a constant as included in the fit coefficients. Similarly, expected future changes of the stratospheric residence time associated with an accelerating stratospheric circulation (Butchart, 2014) are not taken into account in our calculation of the mass-flux-derived ODP from model climate predictions. We expect that changes in the stratospheric residence time only have a small impact on the future ODP compared to the impacts of tropospheric transport and stratospheric chemistry. Thus, we do not take the latter into account in our calculation of future ODP-weighted $\mathrm{CHBr}_{3}$ emissions for the benefit of a computationally efficient method enabling the estimation of future ODP fields.

In addition to changing mass fluxes included in our ODP proxy, changes in stratospheric chemistry will impact the future ODP of $\mathrm{CHBr}_{3}$. In order to account for less effective catalytic ozone destruction, we apply a changing $\alpha$-factor to our ODP fields. The bromine $\alpha$-factor describes the chemical effectiveness of stratospheric bromine in depleting ozone relative to that of chlorine (Daniel et al., 1999) and is set to a global mean value of 60 (Sinnhuber et al., 2009) for the calculation of 1999-2006 ODP fields (Sect. 2.2). As most of the bromine-induced stratospheric ozone loss is caused by the combined $\mathrm{BrO} / \mathrm{ClO}$ catalytic cycle, the effect of bromine (and thus the $\alpha$-factor) is expected to be smaller for decreasing anthropogenic chlorine. We use idealized experiments carried out with the UM-UKCA chemistry-climate model to derive changes in the $\alpha$-factor of brominated VSLSs. The experiments were performed under two different stratospheric chlorine concentrations, corresponding roughly to the beginning $\left(3 \mathrm{ppbv} \mathrm{Cl}_{y}\right)$ and end $\left(0.8 \mathrm{ppbv} \mathrm{Cl}_{y}\right)$ of the 21 st century 
conditions and to $1 \mathrm{xVSLS}$ versus $2 \mathrm{xVSLS}$ loading (see Yang et al., 2014, for details). We calculate the difference between the $2 x$ VSLS and 1xVSLS simulations for both chlorine scenarios to get the overall effect of VSLSs on ozone for the beginning and end of the 21 st century conditions. From the change of this difference from one chlorine scenario to the other, we estimate the global mean $\alpha$-factor applicable for bromine from VSLSs at the end of the century to be around 47. Compared to the current $\alpha$-factor of 60 this is a reduction of about $22 \%$. For simplicity, we assume the stratospheric chlorine loading from 2000 to 2100 to be roughly linear and estimate the $\alpha$-factor within this time period based on a linear interpolation between the 2000 and 2100 values. In a similar manner, we scale the ODP field before 1996 to account for the fact that during this time there was less stratospheric chlorine and a reduced effectiveness of bromine-related ozone depletion. Stratospheric chlorine in 1979 equals roughly the value expected for 2060 (Harris et al., 2014), thus corresponding to a $13 \%$ reduced bromine $\alpha$-factor of 52. ODP values between 1979 and the year 1996, when the amount of stratospheric chlorine reached a peak and started to level off (Carpenter and Reimann, 2014), are estimated based on a linear interpolation over this time period.

\subsection{ODP-weighted $\mathrm{CHBr}_{3}$ emissions}

The concept of ODP-weighted emissions combines information on the emission strength and on the relative ozonedestroying capability of a substance. Its application to VSLSs has been recently rendered possible by the availability of observation-based VSLS emission maps (Ziska et al., 2013). Here, we calculate the present-day ODP-weighted emissions of $\mathrm{CHBr}_{3}$ for data available for 4 months (March, June, September and December) from 1999 to 2006 by multiplying the $\mathrm{CHBr}_{3}$ emissions with the trajectory-derived ODP at each grid point. The resulting ODP-weighted emission maps are given as a function of time (monthly averages) and location $\left(1^{\circ} \times 1^{\circ}\right.$ grid). Global annual means are calculated by averaging over all grid points and over the 4 given months.

In order to extend the time series of ODP-weighted $\mathrm{CHBr}_{3}$ emissions beyond 1999 and 2006, we derive ODP fields from the ERA-Interim upward mass flux. The method is based on the linear polynomial fit determined for the available trajectory-derived $\mathrm{CHBr}_{3}$ ODP fields as described in Sect. 2.3. Multiplying the mass-flux-derived ODP fields with the monthly mean emission fields from Ziska et al. (2013) results in a long-term time series (1979-2013) of ODPweighted $\mathrm{CHBr}_{3}$ emissions. Similarly, we use the CESM1CAM5 mass-flux-derived ODP fields together with emission inventories derived from CESM1-CAM5 meteorological data to produce historical (1979-2005) and future (20062100) model-driven ODP-weighted $\mathrm{CHBr}_{3}$ emission fields.

\section{ODP-weighted $\mathrm{CHBr}_{3}$ emissions for present-day conditions}

We will introduce the concept of the ODP-weighted emissions of $\mathrm{CHBr}_{3}$ exemplarily for March 2005 and discuss how the ODP-weighted emissions of this very short-lived compound compare to those of long-lived halogens. The $\mathrm{CHBr}_{3}$ emissions (Ziska et al., 2013) for March 2005 are shown in Fig. 1a with highest emissions in coastal regions, in the upwelling equatorial waters and the Northern Hemisphere (NH) midlatitude Atlantic. The emissions show large variations and reach values higher than $1500 \mathrm{pmol} \mathrm{m}^{-2} \mathrm{~h}^{-1}$ in coastal regions characterized by high concentrations due to biological productivity and anthropogenic activities. In the tropical open ocean, emissions are often below $100 \mathrm{pmol} \mathrm{m}^{-2} \mathrm{~h}^{-1}$, while in the subtropical gyre regions, ocean and atmosphere are nearly in equilibrium and fluxes are around 0 . Globally, the coastal and shelf regions account for about $80 \%$ of all $\mathrm{CHBr}_{3}$ emissions (Ziska et al., 2013). Apart from the gradients between coastal, shelf and open ocean waters the emissions show no pronounced longitudinal variations. Negative emissions occur in parts of the Southern Ocean, northern $\mathrm{Pa}$ cific and North Atlantic and indicate a $\mathrm{CHBr}_{3}$ sink given by a flux from the atmosphere into the ocean. The evaluation of various $\mathrm{CHBr}_{3}$ emission inventories from Hossaini et al. (2013) shows that in the tropics the best agreement between model and observations is achieved using the bottomup emissions from Ziska et al. (2013). In the extratropics, however, the $\mathrm{CHBr}_{3}$ emissions from Ziska are found to result in too-low atmospheric model concentrations diverging from observations by 40 to $60 \%$.

The potential impact of $\mathrm{CHBr}_{3}$ on the stratospheric ozone layer is displayed in Fig. $1 \mathrm{~b}$ in the form of the ODP of $\mathrm{CHBr}_{3}$ given as a function of time and location of the emissions but independent of its strength. Overall, the ODP of $\mathrm{CHBr}_{3}$ is largest in the tropics (tropical ODP belt) and has low values (mostly below 0.1 ) north and south of $20^{\circ}$. The ODP depends strongly on the efficiency of rapid transport from the ocean surface to the stratosphere which is in turn determined by the intensity of high reaching convection. In the $\mathrm{NH}$ winter/spring of most years, the strongest convection and therefore the highest ODP values of up to 0.85 are found over the equatorial western Pacific (Pisso et al., 2010). In contrast to the $\mathrm{CHBr}_{3}$ emission estimates, the ODP shows pronounced longitudinal variations linked to the distribution of convection and low-level flow patterns.

The ODP-weighted $\mathrm{CHBr}_{3}$ emissions for March 2005 are displayed in Fig. 2. While the emissions themselves describe the strength of the $\mathrm{CHBr}_{3}$ sea-to-air flux, the ODPweighted emissions cannot be interpreted directly as a physical quantity but only relative to ODP-weighted emissions of long-lived halocarbons. The spatial distribution of the ODP-weighted emissions combines information on where large amounts of $\mathrm{CHBr}_{3}$ are emitted from the ocean and where strong vertical transport enables $\mathrm{CHBr}_{3}$ to reach the 

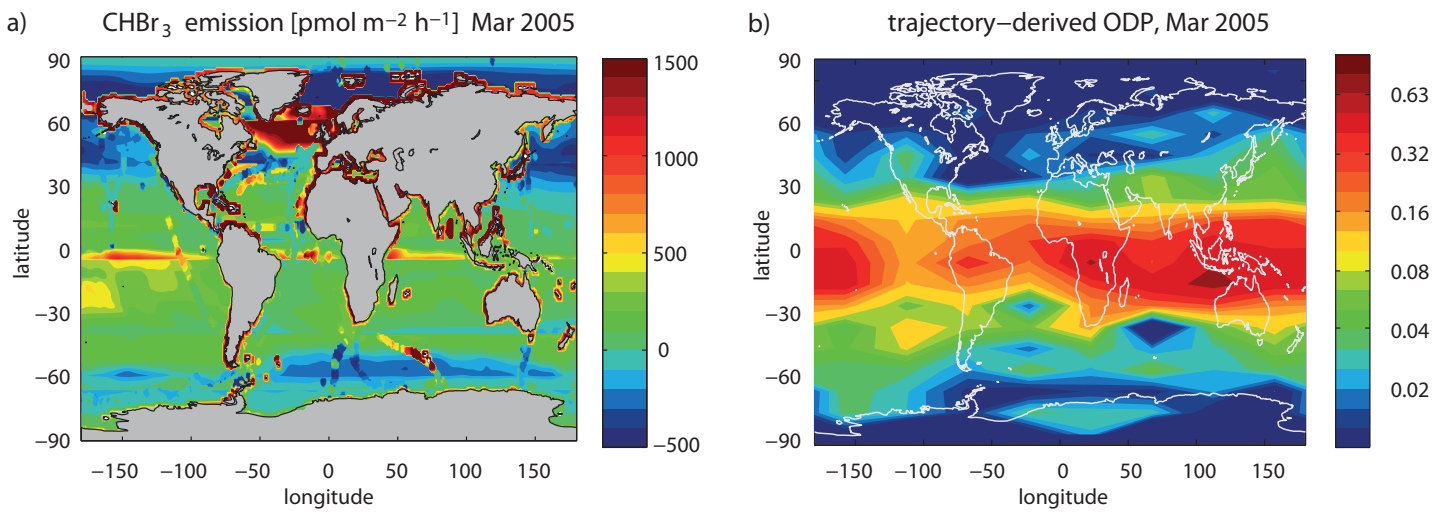

Figure 1. Global $\mathrm{CHBr}_{3}$ emissions (a) and ODP (b) are given for March 2005. The $\mathrm{CHBr}_{3}$ emissions are bottom-up estimates based on the extrapolation of in situ measurements (Ziska et al., 2013). The ODP is given as a function of time and location of emission and was derived based on a Lagrangian approach (Pisso et al., 2010).

stratosphere. Only for regions where both quantities are large, strong ODP-weighted emissions will be found. Regions where one of the quantities is close to 0 will not be important, such as the midlatitude North Atlantic where large $\mathrm{CHBr}_{3}$ emissions occur but the ODP is very low. Negative ODP-weighted emissions occur in regions where the flux is from the atmosphere into the ocean. Since negative ODPweighted emissions are not a meaningful quantity and occur in regions where the ODP is small, they will not be displayed in the following figures and are not taken into account for the calculations of the global mean values. The ODP-weighted emissions are in general largest between $20^{\circ} \mathrm{S}$ and $20^{\circ} \mathrm{N}$ ( $72 \%$ of the overall global amount) as a result of the tropical ODP belt and peak at the Equator and tropical coast lines as a result of the emission distribution. The distribution of the ODP-weighted emissions demonstrates clearly that $\mathrm{CHBr}_{3}$ emissions from the $\mathrm{NH}$ and Southern Hemisphere (SH) extratropics have negligible impact on stratospheric ozone chemistry. Thus, the fact that the emissions from Ziska et al. (2013) might be too low in the extratropics (Hossaini et al., 2013) does not impact our results. Of particular importance for the stratosphere, on the other hand, are emissions from the Maritime Continent (Southeast Asia), the tropical Pacific and the Indian Ocean.

The global annual mean ODP-weighted emissions of $\mathrm{CHBr}_{3}$ are about $40 \mathrm{Gg}_{\text {year }}{ }^{-1}$ for 2005 (Fig. 3) based on the March, June, September and December values of this year. The concept of ODP-weighted emissions becomes particularly useful when comparing this quantity for $\mathrm{CHBr}_{3}$ with the ones of manmade halocarbons. For the year 2005, ODPweighted emissions of $\mathrm{CHBr}_{3}$ amount up to $50 \%$ of the ODP-weighted emissions of methyl bromide $\left(\mathrm{CH}_{3} \mathrm{Br}\right.$, natural and anthropogenic), CFC-11 or CFC-12 $\left(\mathrm{CCl}_{2} \mathrm{~F}_{2}\right)$ and are of similar magnitude as the ODP-weighted emissions of $\mathrm{CCl}_{4}$ and the individual halons. While the ODP of $\mathrm{CHBr}_{3}$ exceeds the value of 0.5 only in less than $10 \%$ of the regions over the globe, the relatively large $\mathrm{CHBr}_{3}$ emissions make up for the overall relatively small ODPs. Current estimates of global $\mathrm{CHBr}_{3}$ emissions range between 249 and $864 \mathrm{Gg} \mathrm{year}^{-1}$ (Ziska et al., 2013, and references therein), with the higher global emission estimates coming from topdown methods while the lower boundary is given by the bottom-up study from Ziska et al. (2013). For our study, even the choice of the lowest emission inventory leads to relatively large ODP-weighted emissions of the very shortlived $\mathrm{CHBr}_{3}$ as discussed above. Choosing a different emission inventory than Ziska et al. (2013) would result in larger ODP-weighted $\mathrm{CHBr}_{3}$ emissions. Still more important than the overall $\mathrm{CHBr}_{3}$ emission strength is the fact that emissions and ODP show similar latitudinal gradients with both fields having higher values at the low latitudes. This spatial coincidence of large sources and efficient transport leads to the relatively large global mean value of ODP-weighted $\mathrm{CHBr}_{3}$ emissions.

It is important to keep in mind that the long-lived halocarbons are to a large degree of anthropogenic origin, while $\mathrm{CHBr}_{3}$ is believed to have mostly natural sources. However, $\mathrm{CHBr}_{3}$ in coastal regions also results from anthropogenic activities such as aquafarming in Southeast Asia (Leedham et al., 2013) and oxidative water treatment (Quack and Wallace, 2003). While these sources accounted for only a small fraction of the global budget in 2003 (Quack and Wallace, 2003), their impact is increasing. In particular, aquafarming used, among other things, for food production and $\mathrm{CO}_{2}$ sequestering has started to increase as an anthropogenic VSLS source. Leedham et al. (2013) estimated tropical halocarbon production from macroalgae in the Malaysian costal region and suggest that only $2 \%$ of the local $\mathrm{CHBr}_{3}$ emissions originate from farmed seaweeds. However, based on recent production growth rates, the Malaysian seaweed aquaculture has been projected to experience a $6-11$-fold increase over the next years (Phang et al., 2010). More importantly, other countries such as Indonesia, Philippines and China are known to produce considerably more farmed seaweed than 


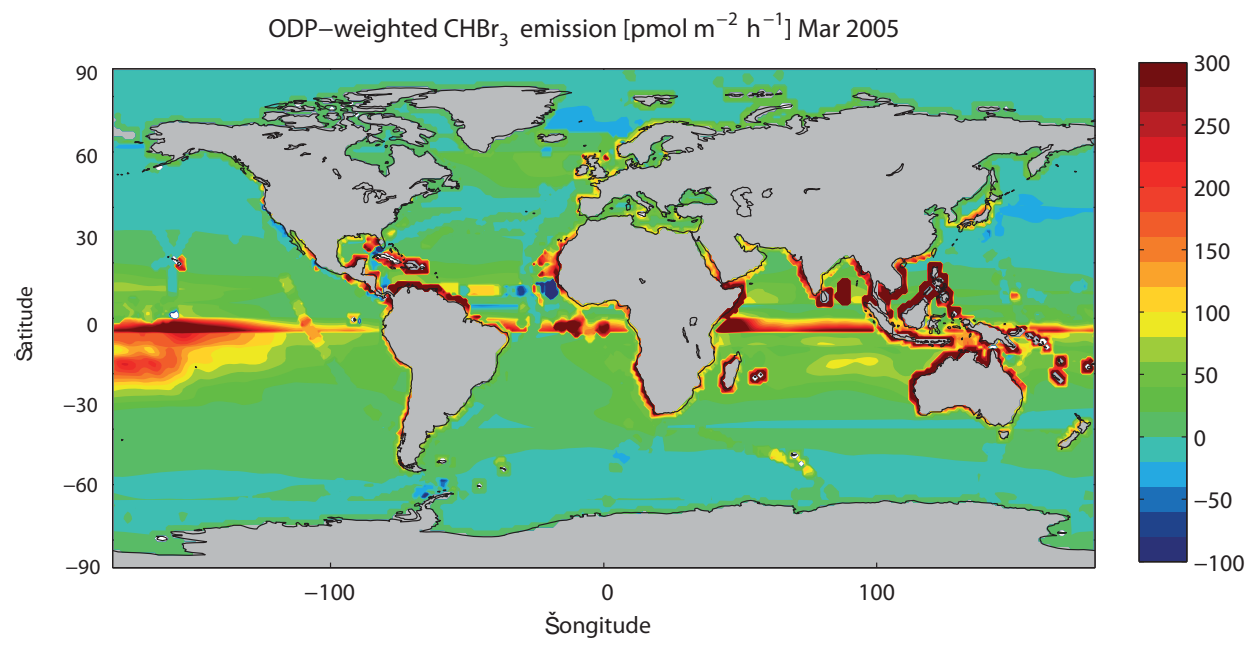

Figure 2. Global ODP-weighted $\mathrm{CHBr}_{3}$ emissions are given for March 2005. The ODP-weighted emissions have been calculated by multiplying the $\mathrm{CHBr}_{3}$ emissions with the ODP at each grid point.

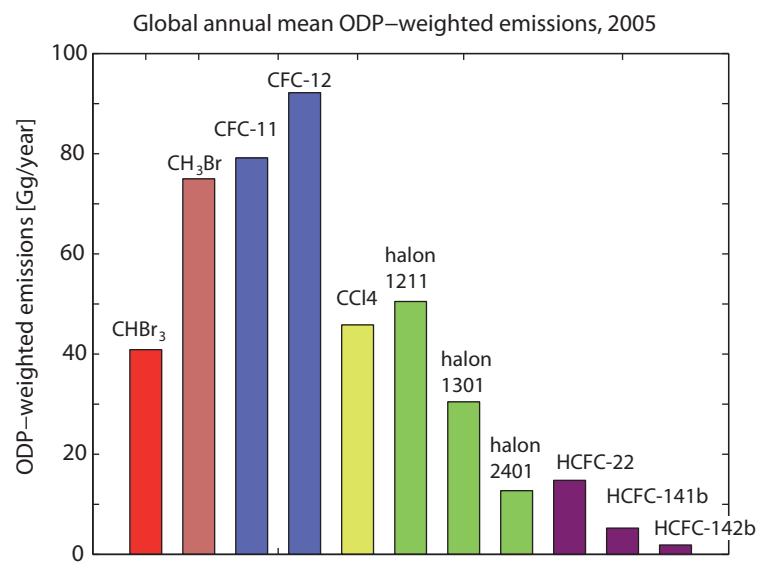

Figure 3. A comparison of the global annual mean ODP-weighted emissions of $\mathrm{CHBr}_{3}$ and long-lived halocarbons is shown for 2005. Emissions of long-lived halocarbons have been derived from NOAA and AGAGE global sampling network measurements (Montzka et al., 2011).

Malaysia (e.g., Tang et al., 2011), but their contribution to the total anthropogenic VSLS emissions has not yet been assessed. The ODP of $\mathrm{CHBr}_{3}$ demonstrates the high sensitivity of the Southeast Asia region to growing emissions. Globally the highest ODP values (Fig. 1b) are found in the same region where we expect future anthropogenic $\mathrm{CHBr}_{3}$ emissions to increase substantially. An assessment of current and future seaweed farming activities including information on farmed species, fresh or dry-weight macroalgal biomass and incubation-derived halocarbon production values is required to estimates the net oceanic aquaculture VSLS production. Since the general ODP concept has been originally defined for anthropogenic halogens, the ODP-weighted $\mathrm{CHBr}_{3}$ emissions should be calculated for the anthropogenic component of the emissions. However, since no such estimates are available at the moment, the method is applied to the combined emission field. Given that the natural oceanic production and emissions of halogenated VSLSs are expected to change in the future due to increasing ocean acidification, changing primary production and ocean surface meteorology (Hepach et al., 2014), it will remain a huge challenge to properly separate natural and anthropogenic emissions of these gases.

\section{ODP proxy}

It is necessary to understand the short- and long-term changes of the ODP-weighted $\mathrm{CHBr}_{3}$ emissions in order to predict their future development. On the seasonal timescales, the ODP-weighted $\mathrm{CHBr}_{3}$ emissions show large variations as demonstrated in Fig. 4 for June and December 2001. In the NH summer, $57 \%$ of the ODP-weighted emissions stem from the $\mathrm{NH}$ tropical belt $\left(30-0^{\circ} \mathrm{N}\right)$ with the largest contributions from the Maritime Continent and Asian coastal areas. In the NH winter, the ODP-weighted emissions shift to the SH tropical belt (48\%) with the strongest contributions from the western Pacific. While the Maritime Continent is an important source region year-round, emissions from the southern coast line of Asia during NH winter are not very important for stratospheric ozone depletion. The emissions reveal some seasonal variations which are most apparent in the Indian Ocean with peak values during $\mathrm{NH}$ summer along the Equator and along the NH coast lines (see Fig. S1 in the Supplement). Note that $\mathrm{CHBr}_{3}$ concentrations maps represent climatological fields and the seasonal variations in the emission fields stem from varying surface winds and sea surface temperature (see Sect. 2.1). Global average $\mathrm{CHBr}_{3}$ emissions show a seasonal cycle of about $25 \%$ with a maximum in July and a minimum in April (Ziska et al., 2013). The seasonal- 


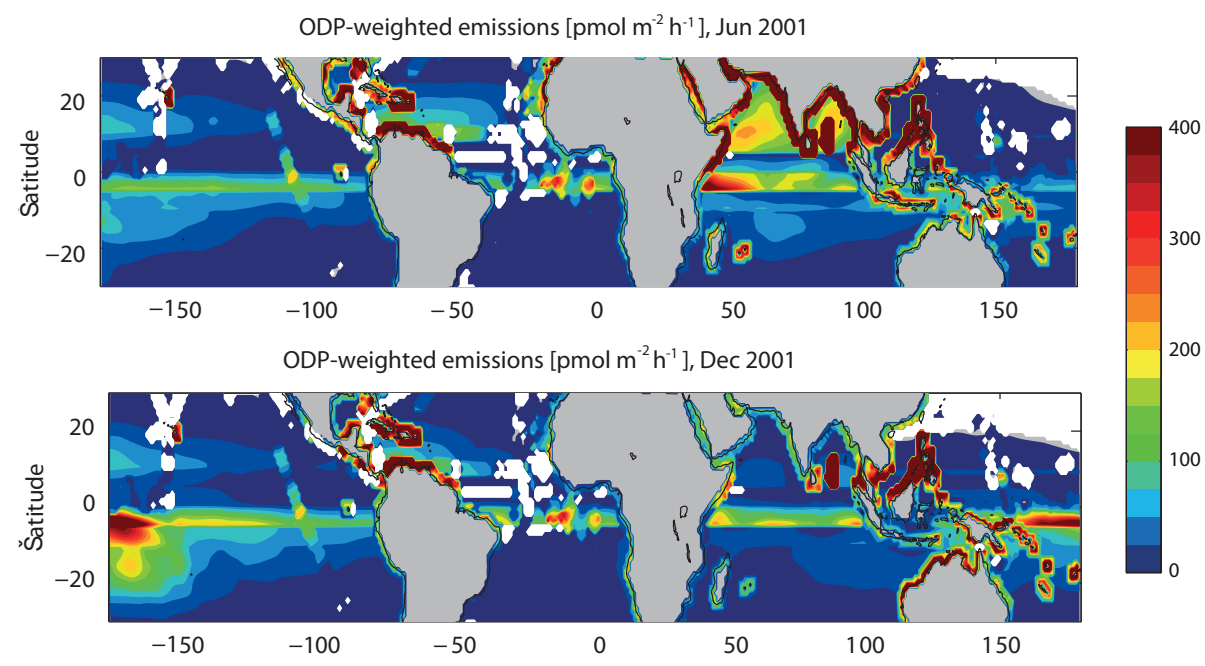

Figure 4. ODP-weighted emissions calculated as the product of the emissions maps (Fig. S1 in the Supplement) and the trajectory-based ODP fields (Fig. 5a) are displayed for June and December 2001.

ity of the ODP (Fig. 5a) driven by the seasonality of deep convection amplifies the seasonal variations in the emissions and thus causes the pronounced shift of the ODP-weighted emissions from one hemisphere to the other.

In order to analyze the long-term changes of ODPweighted $\mathrm{CHBr}_{3}$ emissions, we need to extend the time series beyond the 1999-2006 time period. While $\mathrm{CHBr}_{3}$ emissions are available for 1979-2013, the ODP itself, based on costly trajectory calculations, is restricted to 1999-2006. In order to develop an ODP proxy, we first analyze the variations of the trajectory-derived ODP fields and their relation to meteorological parameters. The ODP fields for the months June and December 2001 (Fig. 5a) have their maxima between 0 and $20^{\circ} \mathrm{N}$ for the $\mathrm{NH}$ summer and $5^{\circ} \mathrm{N}$ and $15^{\circ} \mathrm{S}$ for the $\mathrm{NH}$ winter. In the $\mathrm{NH}$ summer, the dominant source region for stratospheric $\mathrm{CHBr}_{3}$ is located in the equatorial western Pacific region including Southeast Asia. In the $\mathrm{NH}$ winter, the source region is shifted westward and southward with its center now over the western Pacific. These seasonal variations agree with results from previous trajectory studies (e.g., Fueglistaler et al., 2005; Krüger et al., 2008) and are consistent with the main patterns of tropical convection (Gettelman et al., 2002).

A detailed picture of the high-reaching convective activities for June and December is given in Fig. $5 \mathrm{~b}$ in form of the ERA-Interim monthly mean updraught mass flux between 250 and $80 \mathrm{hPa}$. The rapid updraughts transporting air masses from the boundary layer into the tropical tropopause layer (TTL) are part of the ascending branch of the tropospheric circulation constituted by the position of the intertropical convergence zone (ITCZ). The updraught convective mass fluxes are largest in and near the summer monsoon driven circulations close to the Equator. Over the western Pacific and Maritime Continent the region of intense convection is quite broad compared to the other ocean basins due to the large oceanic warm pool and strong monsoon flow. In addition to the overall annual north-south migration pattern, large seasonal changes of the updraught mass flux are visible over South America and the Maritime Continent consistent with the climatological distribution of the ITCZ. The southeastward pointing extension in the Pacific is strongest in the $\mathrm{NH}$ winter and indicates a double ITCZ.

We derive a $\mathrm{CHBr}_{3}$ ODP proxy from the ERA-Interim updraught mass fluxes (referred to as mass-flux-derived ODP, see Sect. 2.3 for details). While the downdraught mass fluxes can also impact (5-15\%) the composition in the upper troposphere/lower stratosphere (Frey et al., 2015), they are not included in our proxy since their importance for the contribution of $\mathrm{CHBr}_{3}$ to stratospheric bromine is less clear and cannot be prescribed by a fit relation. The strong correlation between $\mathrm{CHBr}_{3}$ ODP and high-reaching convection justifies our method by indicating that we capture the most important process for explaining the ODP variability. The mass-fluxderived ODP fields are shown in Fig. 5c and explain 76 and $81 \%$ of the variance of the original trajectory-derived ODP fields (Fig. 5a). Differences between the trajectory-derived ODP fields and the mass-flux-derived proxy may be caused by the fact that not only the location of the most active convective region will determine the ODP distribution but also patterns of low-level flow into these regions. Additionally, spatial and seasonal variations in the expected stratospheric residence time may have a small impact on the trajectoryderived ODP and cause deviations to the mass-flux-derived proxy. Largest disagreement between the trajectory-derived and mass-flux-derived ODP is found over South America and Africa. However, the ODP values over the continents are not important for the ODP-weighted $\mathrm{CHBr}_{3}$ emissions due 
June 2001
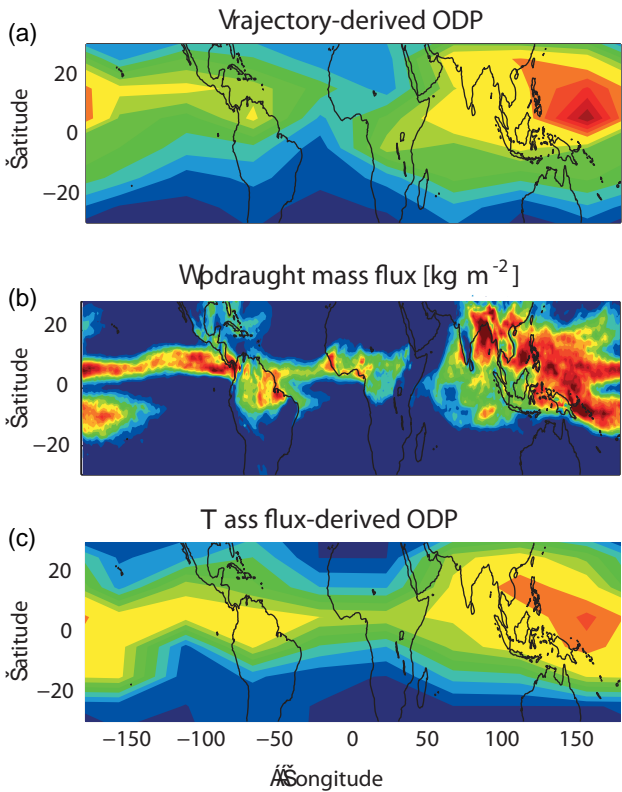

December 2001

7rajectory-derived ODP

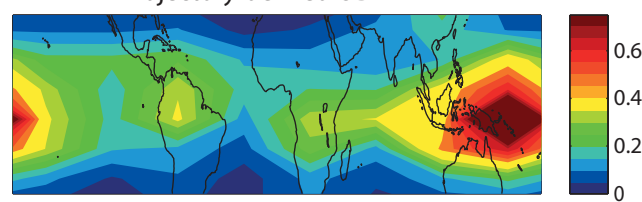

8 pdraught mass flux $\left[\mathrm{kg} \mathrm{m}^{-2}\right]$

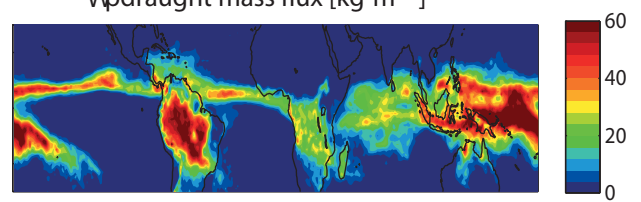

0 ass flux-derived ODP

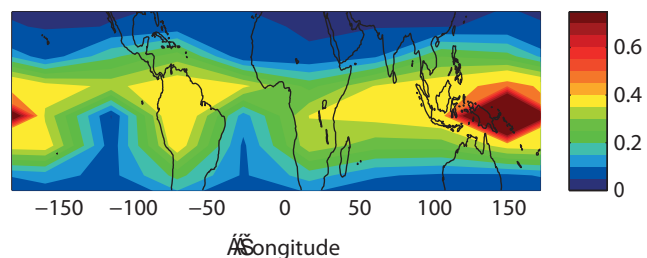

Figure 5. Trajectory-based $\mathrm{CHBr}_{3}$ ODP fields (a), monthly mean ERA-Interim updraught mass flux between 250 and $80 \mathrm{hPa}(\mathbf{b})$ and the mass-flux-derived ODP (c) are displayed for June and December 2001.

to the very low to non-existent emissions over land (Quack and Wallace, 2003) and are not used in our study.

Our analysis confirms that the ODP of species with short lifetimes, such as $\mathrm{CHBr}_{3}$, is to a large degree determined by the high-reaching convective activity (Pisso et al., 2010). As a result, updraught mass-flux fields can be used to derive a proxy of the ODP fields. Such a proxy can also be derived from related meteorological parameters such as the ERA-Interim detrainment rates (not shown here). The ODP proxies identified here provide a cost-efficient method to calculate ODP fields for past (ERA-Interim) and future (climate model output) meteorological conditions. Long-term changes in stratospheric chemistry due to declining chlorine background levels are taken into account by variations of the bromine $\alpha$-factor (see Sect. 2.3 for details). Our method enables us to analyze long-term changes of the ODP and the ODP-weighted emissions, which would otherwise require very large computational efforts.

\section{ODP-weighted $\mathrm{CHBr}_{3}$ emissions for 1979-2013}

Based on the ODP proxy and the correction of the $\alpha$-factor introduced in Sect. 4, we calculate ODP-weighted $\mathrm{CHB}_{3}$ emission fields for the ERA-Interim time period from 1979 to 2013. As a test for our method, we compare the global mean ODP-weighted emissions based on the trajectory- and mass-flux-derived ODP fields for the years 1999-2006. The two time series of ODP-weighted emissions are displayed in Fig. 6 and show a very good agreement with slightly lower mass-flux-derived values (green line) than trajectory-derived values (black line). Individual months can show stronger deviations; e.g., for December 1999 the mass-flux-derived ODP-weighted emissions are about $30 \%$ smaller than the trajectory-derived ones. The pronounced seasonal cycle with maximum values in the $\mathrm{NH}$ summer and autumn is captured by both methods. The seasonal cycle of the global mean values is mostly caused by the very high ODP-weighted emissions along the Southeast Asian coast line which are present during the $\mathrm{NH}$ summer/autumn but not during the $\mathrm{NH}$ winter. The same signal is evident from the $\mathrm{CHBr}_{3}$ emissions itself (see Fig. S1 in the Supplement) and is amplified by the shift of high ODP values to the $\mathrm{NH}$ tropics during $\mathrm{NH}$ summer (Fig. 5a and c). The pronounced seasonal cycle of the ODP-weighted emissions indicates a seasonality of the $\mathrm{CHBr}_{3}$ concentrations in the TTL, which needs to be verified by observations. Note that the ODP-weighted emissions of long-lived halocarbons discussed in Sect. 3 show no strong seasonal variations. The good agreement between the trajectory-derived and the mass-flux-derived ODP-weighted $\mathrm{CHBr}_{3}$ emissions encourages the use of the latter for the analysis of longer time series.

The 35-year-long time series (1979-2013) of ODPweighted $\mathrm{CHBr}_{3}$ emissions is based on the ERA-Interim surface parameters, TTL convective mass flux and a changing bromine $\alpha$-factor (Fig. 7a). The time series is relatively flat over the first 27 years ranging from 34 to $39 \mathrm{Gg}$ year $^{-1}$. Over the last years from 2006 to 2013, a steep increase occurred and ODP-weighted $\mathrm{CHBr}_{3}$ emissions of more than $41 \mathrm{Gg} \mathrm{year}^{-1}$ are reached. In order to analyze which com- 


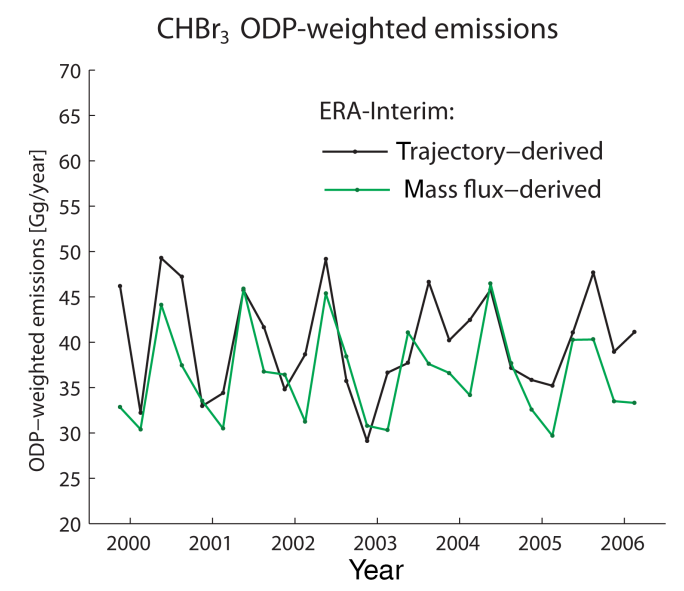

Figure 6. Time series of ODP-weighted $\mathrm{CHBr}_{3}$ emissions based on ERA-Interim trajectory-derived ODP (black line) and mass-fluxderived ODP (green line) for March, June, September and December 1999 to 2006 .

ponent, the mass-flux-derived ODP fields, the oceanic emissions or the stratospheric chemistry, causes this steep increase, three sensitivity studies are performed. In the first study, the emissions vary over the whole time period (19792013), while the ODP field and the bromine $\alpha$-factor are held fixed at their 35-year mean values. Changes in the resulting global mean ODP-weighted emission time series (Fig. 7b) are driven by changes in the emissions alone and show a steady increase over the whole time period of about $2.2 \%$ per decade. This is in agreement with the linear trend of the global mean $\mathrm{CHBr}_{3}$ emissions estimated to be $7.9 \%$ over the whole time period caused by increasing surface winds and sea surface temperatures (Ziska et al., 2015). We do not expect the two trends to be identical, since the ODP-weighted emissions only include emissions in convective active regions, while the global mean emissions correspond to nonweighted mean values including $\mathrm{CHBr}_{3}$ emissions from midand high latitudes.

For the second study, the emission fields and the $\alpha$-factor are kept constant at the 35-year mean values and the massflux-derived ODP is allowed to vary with time. Changes in the resulting, global mean ODP-weighted emission time series (Fig. 7c) are mainly driven by changes in the tropical high-reaching convection and show a negative trend from 1979 to 2005 of $-3.4 \%$ per decade. Over the years 20062013, however, changes in convective activity lead to a steep increase of the ODP-weighted emissions. These changes can either result from a general strengthening of the tropical convective activity or from changing patterns of convective activity, shifting regions of high activity so that they coincide with regions of strong $\mathrm{CHBr}_{3}$ emissions. For the third sensitivity study, the emissions and mass-flux-derived ODP are kept constant at the 35-year mean values, while the $\alpha$-factor varies with time according to the stratospheric chlorine load-
$\mathrm{CHBr}_{3}$ ODP-weighted emissions (ERA-Interim)

(a) Emission-, mass flux- and chemistry driven
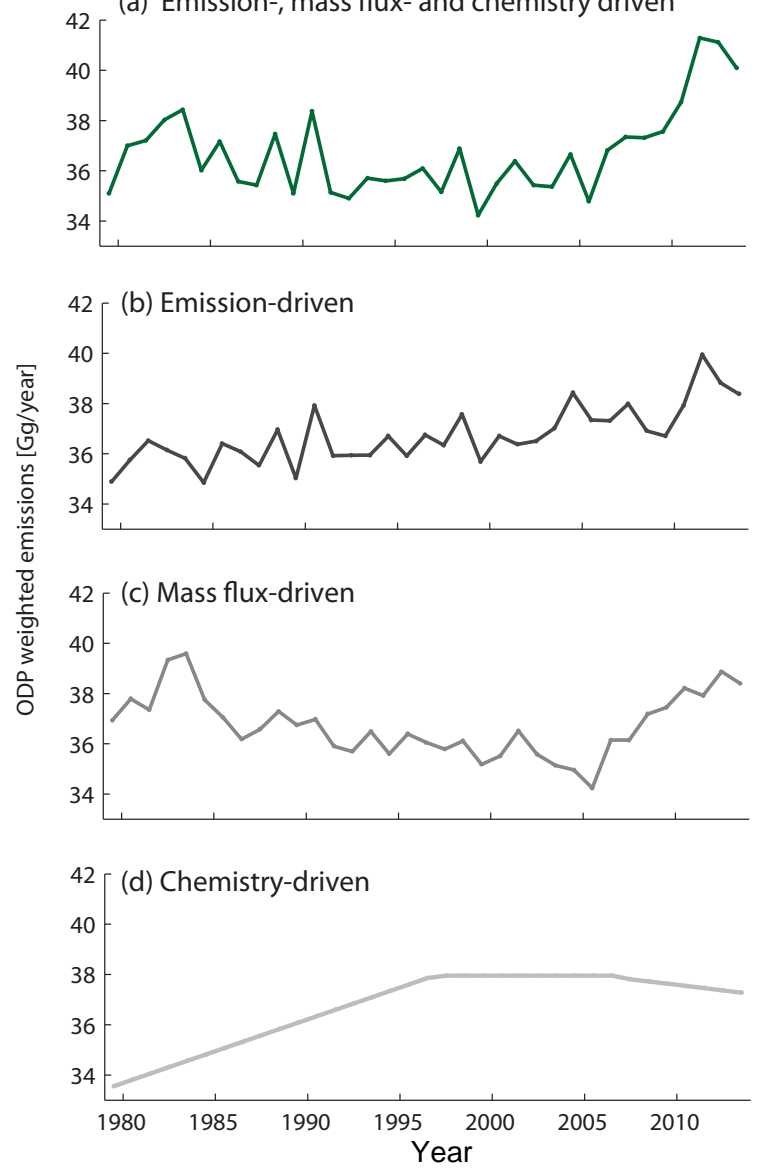

Figure 7. Time series of ODP-weighted $\mathrm{CHBr}_{3}$ emissions for 1979-2013 based on ERA-Interim mass-flux-derived ODP is shown (a). Additionally, sensitivity studies are displayed where two factors are kept constant at their respective 1979-2013 mean values, while the other factor varies with time. The sensitivity studies include ODP-weighted $\mathrm{CHBr}_{3}$ emissions driven by time-varying emissions (b), time-varying mass-flux-derived ODP (c) and timevarying stratospheric chemistry (d).

ing. ODP-weighted $\mathrm{CHBr}_{3}$ emissions increase by $13 \%$ from 1979 to 1999 and peak during the time of the highest stratospheric chlorine loading from 1999 to 2006. Overall, variations of the ODP-weighted $\mathrm{CHBr}_{3}$ emissions induced by the stratospheric chorine-related chemistry are in the same range as the variations induced by changes in convective transport and oceanic emissions.

Combining the conclusions of all three sensitivity studies reveals that for the time period 1979 to 2005, the positive trend of the emissions and the $\alpha$-factor on the one hand and the negative trend of the mass-flux-derived ODP on the other hand mostly cancel out leading to a flat time series of ODP-weighted $\mathrm{CHBr}_{3}$ emissions (Fig. 7a) with no long-term changes. From 2005 to 2013, however, a strong increase in 
ERA-Interim

(a) $\mathrm{CHBr}_{3}$ emissions [pmol m $\mathrm{m}^{-2} \mathrm{~h}^{-1}$ ], Mar 2000

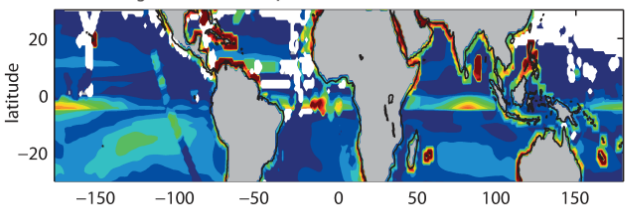

(b) mass flux-derived ODP, Mar 2000

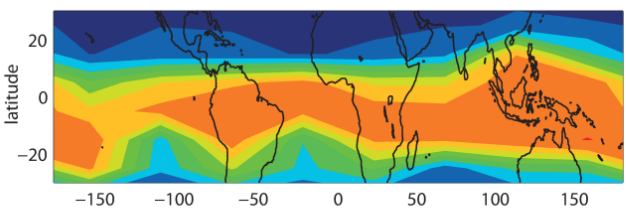

(c) ODP-weighted emissions [pmol m${ }^{-2} \mathrm{~h}^{-1}$ ], Mar 2000

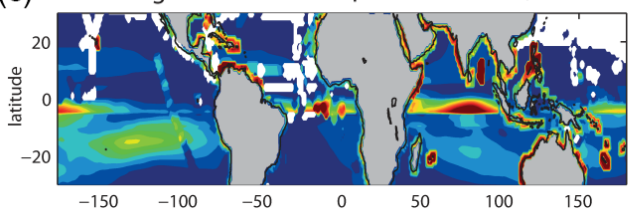

CESM1-CAM5

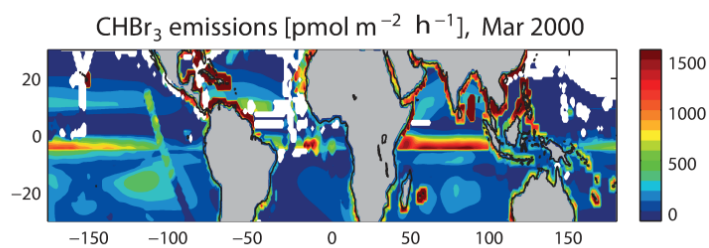

mass flux-derived ODP, Mar 2000

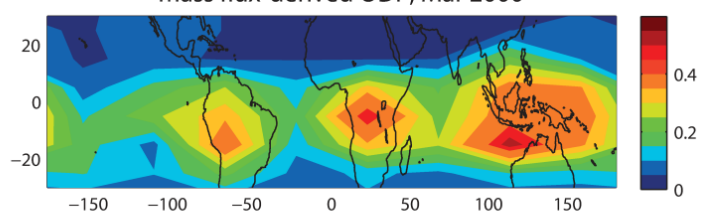

ODP-weighted emissions [pmol $\mathrm{m}^{-2} \mathrm{~h}^{-1}$ ], Mar 2000

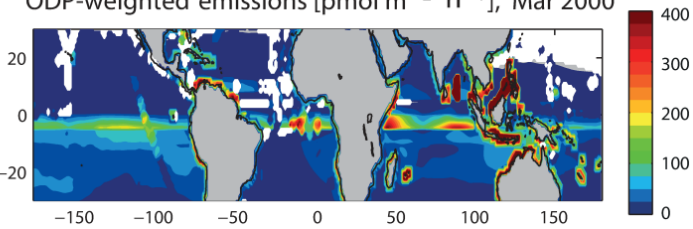

Figure 8. $\mathrm{CHBr}_{3}$ emissions (a), mass-flux-derived ODP (b) and ODP-weighted $\mathrm{CHBr}_{3}$ emissions (c) are shown for ERA-Interim and for CESM1-CAM5 for March 2000.

ODP and continuously increasing emissions lead to a steplike increase of the ODP-weighted $\mathrm{CHBr}_{3}$ emissions from 35 to $41 \mathrm{Gg}_{\text {year }}{ }^{-1}$.

\section{Model-derived ODP-weighted $\mathrm{CHBr}_{3}$ emissions}

We aim to estimate ODP-weighted $\mathrm{CHBr}_{3}$ emissions from earth system model runs. Therefore, we use $\mathrm{CHBr}_{3}$ emissions and the $\mathrm{CHBr}_{3}$ ODP proxy calculated with CESM1CAM5 sea surface temperature, surface wind and upward mass flux (see Sect. 2 for details). In a first step, we evaluate how well the results of our analysis based on the earth system model compare to the results based on ERA-Interim. Figure $8 \mathrm{a}$ shows the distribution of the three quantities, $\mathrm{CHBr}_{3}$ emissions, mass-flux-derived ODP and ODP-weighted emissions, for ERA-Interim and CESM1-CAM5 exemplary for March 2000. The distribution of the emission field is very similar between ERA-Interim and CESM1-CAM5. Largest deviations are found in the Indian Ocean along the Equator, where higher surface winds and temperatures in the model force a stronger sea-to-air flux. Note that in this region, very limited observational data were available for the construction of the emission inventories and future updates will reveal whether these isolated data points are representative of the equatorial Indian Ocean.

The ERA-Interim mass-flux-derived $\mathrm{CHBr}_{3}$ ODP (Fig. 8b) shows an almost zonally uniform region of higher ODP values (around 0.4) extending south of the Equator down to $20^{\circ} \mathrm{S}$. In contrast, the CESM1-CAM5 mass-fluxderived ODP shows only three regions in the deep tropics (the Maritime continent, Africa, South America) with values exceeding 0.3. While the ODP from CESM1-CAM5 show higher local maxima than the ODP from ERA-Interim, the globally averaged ODP field is larger for the reanalysis data than for the model. As a result, the ODP-weighted $\mathrm{CHBr}_{3}$ emissions (Fig. 8c) based on reanalysis data are higher in most of the tropics. Particularly, in the eastern Pacific and Indian Ocean large-scale features of enhanced ODP-weighted $\mathrm{CHBr}_{3}$ emissions exist for ERA-Interim but not for the earth system model. However, enhanced ODP-weighted emissions along some coast lines are present in the model results (e.g., Indonesia) but are not as pronounced in ERA-Interim. Overall, the ODP-weighted $\mathrm{CHBr}_{3}$ emissions for March 2000 based on ERA-Interim and CESM1-CAM5 show similar distribution and similar magnitude. The model-derived values are slightly smaller than the observation-derived values mostly as a result of less high-reaching convective activity in the model.

We compare the global mean ODP-weighted $\mathrm{CHBr}_{3}$ emissions based on the ERA-Interim reanalysis data (observation derived) to the same quantity from the CESM1-CAM5 historical model run for the 1999-2006 time period (Fig. 9). The historical ODP-weighted emissions from CESM1-CAM5 show larger variations than the observation-derived time series. The stronger variability is caused by a stronger variability in the ODP time series possibly related to larger meteorological fluctuations in the earth system model during this short time period. The overall magnitude as well as the phase and amplitude of the seasonal cycle are captured reasonably well by CESM1-CAM5, lending confidence in the use of the model to estimate ODP-weighted $\mathrm{CHBr}_{3}$ emissions for $\mathrm{fu}$ - 


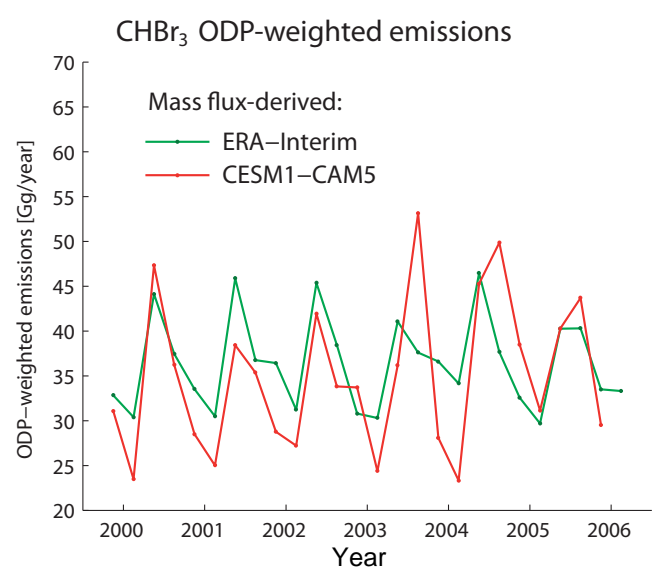

Figure 9. Time series of $\mathrm{CHBr}_{3}$ ODP-weighted emissions based on ERA-Interim (green line) and on historical CESM1-CAM5 runs (red line) are shown. The ODP is calculated from the updraught mass-flux fields.

ture climate scenarios. Recent improvements have been reported in the regional cloud representation in the deep convective tropical Pacific (Kay et al., 2012) and in the parameterization of deep convection and ENSO simulation (Neale et al., 2008). Overall, our analysis demonstrates that the spatial and seasonal variability of the model fields allow us to derive realistic ODP-weighted $\mathrm{CHBr}_{3}$ emission estimates.

\section{ODP-weighted $\mathrm{CHBr}_{3}$ emissions for 2006-2100}

Future ODP-weighted $\mathrm{CHBr}_{3}$ emissions shown in Fig. 10a are based on future model estimates of the $\mathrm{CHBr}_{3}$ emissions and the $\mathrm{CHBr}_{3}$ ODP proxy. Both quantities are calculated based on the meteorological and marine surface variables and convective mass flux from the CESM1-CAM5 RCP 8.5 runs. In addition, we have applied a correction factor to the ODP fields to account for a changing $\alpha$-factor based on less effective ozone loss cycles in the stratosphere due to the decrease of anthropogenic chlorine (Sect. 2.3). The future estimates of the ODP-weighted $\mathrm{CHBr}_{3}$ emissions show pronounced interannual variations of up to $20 \%$. Overall, the ODP-weighted emissions increase steadily until 2100 by about $31 \%$ of the 2006-2015 mean value corresponding to a linear trend of $2.6 \%$ per decade.

In order to analyze what causes the strong interannual variability and the long-term trend, we conduct sensitivity studies where only one factor (emissions, mass-flux-derived ODP, stratospheric chemistry) changes while the other two are kept constant. Figure 10b displays the time series of ODP-weighted $\mathrm{CHBr}_{3}$ emissions for varying oceanic emission fields. The emission-driven time series for 2006-2100 shows a positive trend of $2.2 \%$ per decade which is very similar to the trend observed for the emission-driven time series for 1979-2013 based on ERA-Interim (Fig. 7b). How-

$$
\mathrm{CHBr}_{3} \text { ODP-weighted emissions (CESM1-CAM5) }
$$

(a) Emission-, mass flux- and chemistry driven

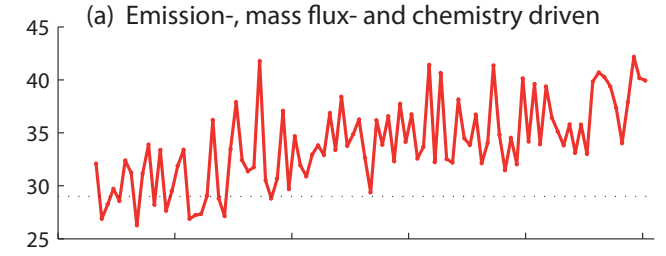

(b) Emission-driven

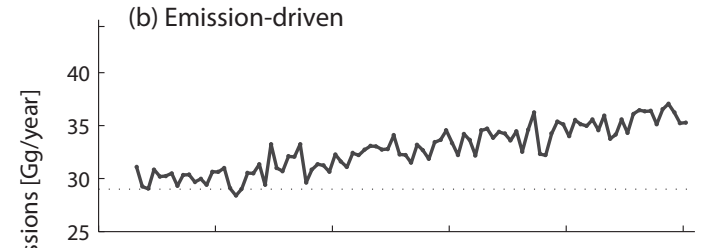

(c) Mass flux-driven
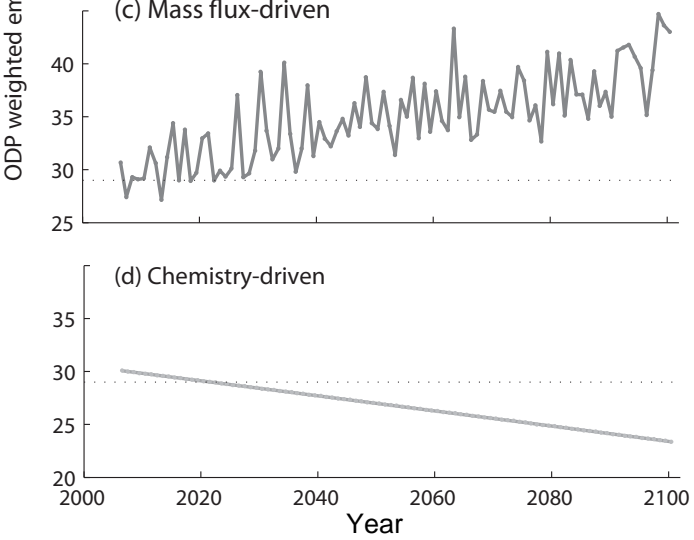

Figure 10. Time series of $\mathrm{CHBr}_{3}$ ODP-weighted emissions for 2006-2100 based on future (RCP 8.5 scenario) CESM1-CAM5 runs are shown (a). Additionally, the future time series are displayed with two factors kept constant at their respective 2006-2015 mean value while the other factor varies with time. The sensitivity studies include ODP-weighted $\mathrm{CHBr}_{3}$ emissions driven by time-varying emissions (b), time-varying mass-flux-derived ODP (c) and timevarying stratospheric chemistry (d).

ever, the model-based ODP-weighted emissions show no long-term change over the first 15 years and the positive, emission-driven trend only starts after 2020. The second sensitivity study (Fig. 10c) highlights changes in the ODPweighted emissions attributable to high-reaching convection (via the mass-flux-derived ODP), while emission fields and $\alpha$-factor are kept constant. Clearly, the strong interannual variations in the combined time series (Fig. 10a) are caused by the same fluctuations in the mass-flux-driven time series. In comparison, the interannual variability of the emissiondriven time series is less pronounced. The projected changes in atmospheric transport cause a positive trend of the ODPweighted emissions of about $3.1 \%$ per decade. This positive trend projection in the mass-flux-derived ODP reveals a future change in the tropical circulation with significant consequences for trace gas transport from the troposphere into the stratosphere. More detailed evaluations demonstrate that 


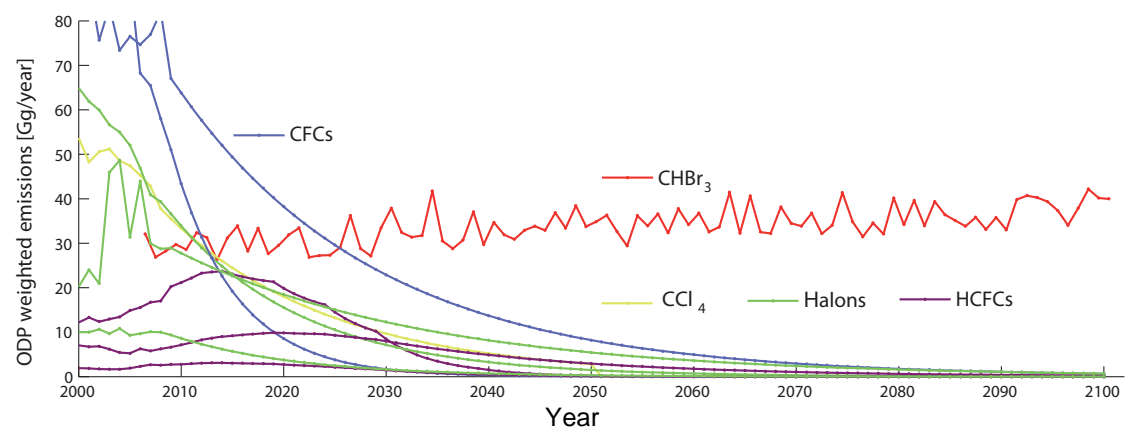

Figure 11. Future projections of annual mean ODP-weighted emissions of $\mathrm{CHBr}_{3}$ and other long-lived halocarbons are shown for 20002100. Future ODP-weighted emission estimates for long-lived halocarbons (halons: halon 1211, 1301, 2402; HCFCs: HCFC-22, -141, -142) are shown.

the CESM1-CAM5 tropical convective upward mass flux is projected to decrease in the lower and middle troposphere (not shown here) in agreement with results from UKCA chemistry-climate model simulations (Hossaini et al., 2012). Contrary to the changes in the middle troposphere, the convective mass flux in the upper troposphere (above the $250 \mathrm{hPa}$ level) is projected to increase in the future, again in agreement with Hossaini et al. (2012). A higher extension of tropical deep convection has also been found in other model projections, and increasing greenhouse-gas-induced tropospheric warming leading to an uplift of the tropopause has been suggested as the possible cause (Chou and Chen, 2010; Rybka and Tost, 2014). Overall, an increasing upward mass flux in the upper troposphere/lower stratosphere would lead to enhanced entrainment of $\mathrm{CHBr}_{3}$ into the stratosphere, consistent with results from Hossaini et al. (2012) and Dessens et al. (2009), and thus to increasing ODP-weighted emissions. Finally, for the last sensitivity study, the chemistry-driven time series of the ODP-weighted emissions shows no interannual variability and a negative trend of $-2.6 \%$ per decade. Decreasing anthropogenic chlorine emissions and thus a less efficient $\mathrm{BrO} / \mathrm{ClO}$ ozone loss cycle leads to a reduction of bromine-related ozone depletion of $22 \%$ as prescribed by the results of the idealized chemistry-climate model experiments from Yang et al. (2014).

In summary, changing emissions and changing convection would lead to a projected increase of $5.4 \%$ per decade of the ODP-weighted emissions over the 21st century for the RCP 8.5 scenario. However, due to declining anthropogenic chlorine, stratospheric ozone chemistry will become less effective and the corresponding decreasing $\alpha$-factor reduces the ODPweighted $\mathrm{CHBr}_{3}$ emissions, resulting in an overall projected trend of about $2.6 \%$ per decade.

A comparison of the model-derived $\mathrm{CHBr}_{3}$ ODPweighted emissions with those of other long-lived substances is shown in Fig. 11. For the other ozone-depleting substances included in the comparison, changing emissions are taken into account by applying their potential emission scenarios (Velders et al., 2007; Ravishankara et al., 2009). The ODP of CFC-11 is nearly independent of the stratospheric chlorine levels (Ravishankara et al., 2009) and is thus kept constant for the whole time period. The same is assumed for all other long-lived halocarbons included in the comparison. Our comparison shows that emissions of the short-lived $\mathrm{CHBr}_{3}$ can be expected to have a larger impact on stratospheric ozone than the other anthropogenic halocarbons after approximately 2025 (Fig. 11). Two exceptions to this are ODP-weighted emissions of $\mathrm{CH}_{3} \mathrm{Br}$ and anthropogenic $\mathrm{N}_{2} \mathrm{O}$ (Ravishankara et al., 2009), both of which are not shown in our plot.

$\mathrm{CH}_{3} \mathrm{Br}$, with partially anthropogenic and partially natural sources, is not included in the comparison, since neither an potential emission scenario nor an estimate on how changes in atmospheric transport will impact its ODP is available at the moment. If we assume a $\mathrm{CH}_{3} \mathrm{Br}$ scenario with constant emissions from natural and anthropogenic sources and a constant $\alpha$-factor, its ODP-weighted emissions would be around $70 \mathrm{Gg}$ year $^{-1}$ over the 21 st century. However, we know this to be unrealistic and expect changes in anthropogenic $\mathrm{CH}_{3} \mathrm{Br}$ emissions and a decreasing $\alpha$-factor, both of which would lead to smaller projections of its ODP-weighted emissions. $\mathrm{N}_{2} \mathrm{O}$ emissions have been projected to be the most important ozone-depleting emissions in the future with ODP-weighted emissions between 100 and $300 \mathrm{Gg}_{\text {year }}{ }^{-1}$ expected for the end of the century (Ravishankara et al., 2009).

\section{Discussion and summary}

The ODP-weighted emissions of $\mathrm{CHBr}_{3}$ give a detailed picture of where and when oceanic $\mathrm{CHBr}_{3}$ emissions take place that will later impact stratospheric ozone. Furthermore, they provide a useful tool of comparing the emission strength of $\mathrm{CHBr}_{3}$ with those of long-lived anthropogenic gases in an ozone depletion framework. Since currently no information is available on the strength of anthropogenic $\mathrm{CHBr}_{3}$ emissions, the ODP concept is applied to the complete emission budget including the natural oceanic contribution. While we focus our analysis on one VSLS and introduce the method 
and application within a case-study framework for $\mathrm{CHBr}_{3}$, the concept can be applied to all VSLSs where emissions and ODP are available at a spatial resolution necessary to describe their variability.

While the ODP-weighted emissions are an important step towards assessing the current and future effects of VSLSs on the ozone layer, one needs to keep in mind that the absolute values are subject to large uncertainties arising from uncertainties in the emission inventories and in the parameterization of the convective transport. Existing global $\mathrm{CHBr}_{3}$ emission inventories show large discrepancies due to sparse observational data sets and have particularly high uncertainties in coastal regions due to differing types and amounts of macroalgae (Carpenter and Reimann, 2014). We have used the Ziska et al. (2013) emission inventory, which suggests a lower flux of $\mathrm{CHBr}_{3}$ from the tropical oceans to the atmosphere than other inventories. Based on comparison of the emission inventories in Hossaini et al. (2013) we would expect that the application of a different emission scenario in our approach could lead to a 2- to 3-fold increase in ODPweighted emissions. However, for the tropics, the relatively low emissions from Ziska et al. (2013) provide the best fit with the limited available atmospheric data (Hossaini et al., 2013). The sensitivity of our results to uncertainties in transport becomes apparent when we apply the ODP fields calculated from FLEXPART trajectories without taking into account convective parameterization (Pisso et al., 2010). The ODP calculated without convective parameterization results in roughly $50 \%$ lower global mean ODP-weighted $\mathrm{CHBr}_{3}$ emissions. Additionally, uncertainties may arise from the simplified tropospheric and stratospheric chemistry schemes with an altitude-independent $\alpha$-factor and a prescribed tropospheric lifetime. Further detailed studies including different convective parameterization schemes, more detailed representation of tropospheric chemistry, product gas impacts, various emission inventories and multi-model mean scenarios are required in order to obtain reliable uncertainty ranges which need to be included in any communication of ODPs to policy makers.

Our analysis reveals that the spatial variability of trajectory-derived ODP fields of species with short lifetimes, such as $\mathrm{CHBr}_{3}$, is to a large degree determined by deep tropical convection. As a result, a cost-efficient method to calculate ODP field proxies from updraught mass flux fields has been developed and applied. Past ODP-weighted $\mathrm{CHBr}_{3}$ emission estimates have been derived based on ERA-Interim meteorological fields. For the time period 1979 to 2005, a positive trend in the $\mathrm{CHBr}_{3}$ emissions and a negative trend in mass-flux-derived ODP mostly cancel out, leading to a flat time series of ODP-weighted emissions with no longterm changes. From 2006 to 2013, however, a strong increase in both quantities leads to a step-like increase of the ODPweighted $\mathrm{CHBr}_{3}$ emissions.

Future ODP-weighted $\mathrm{CHBr}_{3}$ emission estimates have been derived from CESM1-CAM5 RCP 8.5 runs taking into account changing meteorological and marine surface parameters, convective activity and stratospheric chemistry. Changes in tropospheric chemistry and stratospheric residence time are not taken into account for the calculation of the future ODP-weighted emissions. While our methodology is somewhat limited by these simplifications, $\mathrm{CHBr}_{3}$ delivery from the surface to the tropopause in a future changing climate is expected to be mostly related to changes in tropospheric transport rather than changes in tropospheric chemistry (Hossaini et al., 2013), suggesting that we include the most important processes here. Furthermore, we do not account for changing biogeochemistry in the ocean and anthropogenic activities that can lead to increasing $\mathrm{CHBr}_{3}$ emissions and further amplify the importance of VSLSs for stratospheric ozone chemistry. Such changes in the oceanic sources are important for estimating the future impact of VSLSs on atmospheric processes, but they are not understood well enough yet to derive reliable future projections. Finally, we do not consider potential future changes in stratospheric aerosol which could impact the contribution of VSLSs to stratospheric ozone depletion (Salawitch et al., 2005; Sinnhuber et al., 2009). Variations in the background stratospheric aerosol loading (e.g., Vernier et al., 2011) are mostly attributed to minor volcanic eruptions (Neely et al., 2013). Since future volcanic eruptions are not accounted for in the simulations scenarios used here, we do not include the impact of natural aerosol variations. Suggested future geoengineering would intentionally enhance the stratospheric aerosol loading and is projected to increase the impact of VSLSs on stratospheric ozone by as much as $2 \%$ at high latitudes (Tilmes et al., 2012). Such a scenario is not included in our simulations but could effectively enhance the ODP of $\mathrm{CHBr}_{3}$ due to an enhanced $\mathrm{BrO} / \mathrm{ClO}$ ozone loss cycle in the lower stratosphere (Tilmes et al., 2012). Overall, some discrepancies between the observation- and modelderived ODP-weighted $\mathrm{CHBr}_{3}$ emissions exist, very likely related to out-of-phase tropical meteorology in the model. However, there is general good agreement between the spatial and seasonal variability of the observation- and modelderived fields, encouraging the use of this model to derive realistic ODP-weighted $\mathrm{CHBr}_{3}$ emission estimates.

Variability of the ODP-weighted $\mathrm{CHBr}_{3}$ emissions on different timescales are driven by different processes. Spatial and seasonal variations are caused by variations in the surface to tropopause transport via deep convection. Interannual variability is mostly driven by transport variations but also by the variability of the oceanic emissions. Both processes are weakly correlated on interannual timescales (with a Pearson correlation coefficient between the interannual anomalies of $r=0.3$ ), suggesting that in years with stronger emissions (driven by stronger surface winds and higher temperatures) stronger troposphere-to-stratosphere transport exist. The long-term trend, finally, can be attributed in equal parts to changes in emissions, troposphere-to-stratosphere transport and stratospheric chemistry. While growing oceanic 
emissions and changing convective activity lead to increasing ODP-weighted $\mathrm{CHBr}_{3}$ emissions, the expected decline in stratospheric chlorine background levels has the opposite effect and leads to a decrease. Taking all three processes into account, the future model projections suggest a $31 \%$ increase of the 2006 ODP-weighted $\mathrm{CHBr}_{3}$ emissions until 2100 for the RCP 8.5 scenario. This anthropogenically driven increase will further enhance the importance of $\mathrm{CHBr}_{3}$ for stratospheric ozone chemistry.

\section{The Supplement related to this article is available online at doi:10.5194/acp-15-13647-2015-supplement.}

Acknowledgements. The authors are grateful to the ECMWF for making the reanalysis product ERA-Interim available. This study was carried out within the EU project SHIVA (FP7-ENV-2007-1226224) and the BMBF project ROMIC THREAT (01LG1217A). We thank Steve Montzka for helpful discussions.

Edited by: P. Haynes

\section{References}

Aschmann, J. and Sinnhuber, B.-M.: Contribution of very shortlived substances to stratospheric bromine loading: uncertainties and constraints, Atmos. Chem. Phys., 13, 1203-1219, doi:10.5194/acp-13-1203-2013, 2013.

Austin, J. N. and Butchart, N.: Coupled chemistry-climate model simulations for the period 1980 to 2020: ozone depletion and the start of ozone recovery, Q. J. Roy. Meteor. Soc., 129, 3225-3249, 2003

Braesicke, P., Keeble, J., Yang, X., Stiller, G., Kellmann, S., Abraham, N. L., Archibald, A., Telford, P., and Pyle, J. A.: Circulation anomalies in the Southern Hemisphere and ozone changes, Atmos. Chem. Phys., 13, 10677-10688, doi:10.5194/acp-1310677-2013, 2013.

Brioude, J., Portmann, R. W., Daniel, J. S., Cooper, O. R., Frost, G. J., Rosenlof, K. H., Granier, C., Ravishankara, A. R., Montzka, S. A., and Stohl, A.: Variations in ozone depletion potentials of very short-lived substances with season and emission region, Geophys. Res. Lett., 37, L19804, doi:10.1029/2010GL044856, 2010.

Butchart, N.: The Brewer-Dobson circulation, Rev. Geophys., 52, 157-184, doi:10.1002/2013RG000448, 2014.

Carpenter, L. J. and Reimann, S. (Lead Authors), Burkholder, J. B., Clerbaux, C., Hall, B. D., Hossaini, R., Laube, J. C., and YvonLewis, S. A.: Ozone-Depleting Substances (ODSs) and Other Gases of Interest to the Montreal Protocol, Chapter 1 in Scientific Assessment of Ozone Depletion: 2014, Global Ozone Research and Monitoring Project-Report No. 55, World Meteorological Organization, Geneva, Switzerland, 2014.

Chou, C. and Chen, C.: Depth of Convection and the Weakening of Tropical Circulation in Global Warming, J. Climate, 23, 30193030, doi:10.1175/2010JCLI3383.1, 2010.
Daniel, J. S., Solomon, S., Portmann, R. W., and Garcia, R. R.: Stratospheric ozone destruction: The importance of bromine relative to chlorine, J. Geophys. Res., 104, 23871-23880, 1999.

Dee, D. P., Uppala, S. M., Simmons, A. J., Berrisford, P., Poli, P., Kobayashi, S., Andrae, U., Balmaseda, M. A., Balsamo, G., Bauer, P., Bechtold, P., Beljaars, A. C. M., van de Berg, L., Bidlot, J., Bormann, N., Delsol, C., Dragani, R., Fuentes, M., Geer, A. J., Haimberger, L., Healy, S. B., Hersbach, H., Hólm, E. V., Isaksen, L., Kållberg, P., Köhler, M., Matricardi, M., McNally, A. P., Monge-Sanz, B. M., Morcrette, J.-J., Park, B.-K., Peubey, C., de Rosnay, P., Tavolato, C., Thépaut, J.-N. and Vitart, F.: The ERA-Interim reanalysis: configuration and performance of the data assimilation system, Q. J. Roy. Meteor. Soc., 137, 553-597, doi:10.1002/qj.828, 2011.

Dessens, O., Zeng, G., Warwick, N., and Pyle, J.: Short-lived bromine compounds in the lower stratosphere; impact of climate change on ozone, Atmos. Sci. Lett., 10, 201-206, 2009.

Dorf, M., Butler, J. H., Butz, A., Camy-Peyret, C., Chipperfield, M. P., Kritten, L., Montzka, S. A., Simmes, B., Weidner, F., and Pfeilsticker, K.: Long-term observations of stratospheric bromine reveal slow down in growth, Geophys. Res. Lett., 33, L24803, doi:10.1029/2006GL027714, 2006.

Frey, W., Schofield, R., Hoor, P., Kunkel, D., Ravegnani, F., Ulanovsky, A., Viciani, S., D'Amato, F., and Lane, T. P.: The impact of overshooting deep convection on local transport and mixing in the tropical upper troposphere/lower stratosphere (UTLS), Atmos. Chem. Phys., 15, 6467-6486, doi:10.5194/acp-15-64672015, 2015.

Fueglistaler, S., Bonazzola, M., Haynes, P. H., and Peter, T.: Stratospheric water vapor predicted from the Lagrangian temperature history of air entering the stratosphere in the tropics, J. Geophys. Res., 110, D08107, doi:10.1029/2004JD005516, 2005.

Gettelman, A., Salby, M. L., and Sassi, F.: Distribution and influence of convection in the tropical tropopause region, J. Geophys. Res., 107, ACL6.1-ACL6.12, doi:10.1029/2001JD001048, 2002.

Harris, N. R. P., Wuebbles, D. J., Daniel, J. S., Hu, J., Kuijpers, L. J. M., Law, K. S., Prather, M. J., and Schofield, R.: Scenarios and Information for Policymakers, Chapter 5 in Scientific Assessment of Ozone Depletion: 2014, Global Ozone Research and Monitoring Project-Report No. 55, World Meteorological Organization, Geneva, Switzerland, 2014.

Hepach, H., Quack, B., Ziska, F., Fuhlbrügge, S., Atlas, E. L., Krüger, K., Peeken, I., and Wallace, D. W. R.: Drivers of diel and regional variations of halocarbon emissions from the tropical North East Atlantic, Atmos. Chem. Phys., 14, 1255-1275, doi:10.5194/acp-14-1255-2014, 2014.

Hossaini, R., Chipperfield, M. P., Dhomse, S., Ordóñez, C., SaizLopez, A., Abraham, N. L., Archibald, A., Braesicke, P., Telford, P., and Warwick, N.: Modelling future changes to the stratospheric source gas injection of biogenic bromocarbons, Geophys. Res. Lett., 39, L20813, doi:10.1029/2012GL053401, 2012.

Hossaini, R., Mantle, H., Chipperfield, M. P., Montzka, S. A., Hamer, P., Ziska, F., Quack, B., Krüger, K., Tegtmeier, S., Atlas, E., Sala, S., Engel, A., Bönisch, H., Keber, T., Oram, D., Mills, G., Ordóñez, C., Saiz-Lopez, A., Warwick, N., Liang, Q., Feng, W., Moore, F., Miller, B. R., Marécal, V., Richards, N. A. D., Dorf, M., and Pfeilsticker, K.: Evaluating global emission in- 
ventories of biogenic bromocarbons, Atmos. Chem. Phys., 13, 11819-11838, doi:10.5194/acp-13-11819-2013, 2013.

Hossaini, R., Chipperfield, M. P., Montzka, S. A., Rap, A., Dhomse, S., and Feng, W.: Efficiency of short-lived halogens at influencing climate through depletion of stratospheric ozone, Nat. Geosci., 8, 186-190, doi:10.1038/ngeo2363, 2015.

Leedham, E. C., Hughes, C., Keng, F. S. L., Phang, S.-M., Malin, G., and Sturges, W. T.: Emission of atmospherically significant halocarbons by naturally occurring and farmed tropical macroalgae, Biogeosciences, 10, 3615-3633, doi:10.5194/bg-10-36152013, 2013.

Kay, J. E., Hillman, B., Klein, S., Zhang, Y., Medeiros, B., Gettelman, G., Pincus, R., Eaton, B., Boyle, J., Marchand, R., and Ackerman, T.: Exposing global cloud biases in the Community Atmosphere Model (CAM) using satellite observations and their corresponding instrument simulators, J. Climate, 25, 5190-5207, 2012.

Krüger, K., Tegtmeier, S., and Rex, M.: Long-term climatology of air mass transport through the Tropical Tropopause Layer (TTL) during NH winter, Atmos. Chem. Phys., 8, 813-823, doi:10.5194/acp-8-813-2008, 2008.

Liang, Q., Stolarski, R. S., Kawa, S. R., Nielsen, J. E., Douglass, A. R., Rodriguez, J. M., Blake, D. R., Atlas, E. L., and Ott, L. E.: Finding the missing stratospheric Bry: a global modeling study of $\mathrm{CHBr}_{3}$ and $\mathrm{CH}_{2} \mathrm{Br}_{2}$, Atmos. Chem. Phys., 10, 2269-2286, doi:10.5194/acp-10-2269-2010, 2010.

Liang, Q., Atlas, E., Blake, D., Dorf, M., Pfeilsticker, K., and Schauffler, S.: Convective transport of very short lived bromocarbons to the stratosphere, Atmos. Chem. Phys., 14, 5781-5792, doi:10.5194/acp-14-5781-2014, 2014.

Montzka, S. A., Krol, M., Dlugokencky, E., Hall, B., Jöckel, P., and Lelieveld, J.: Small Interannual Variability of Global Atmospheric Hydroxyl, Science, 331, 67-69, doi:10.1126/science.1197640, 2011.

Neale, R. B., Richter, J. H., and Jochum, M.: The impact of convection on ENSO: From a delayed oscillator to a series of events, J. Climate, 21, 5904-5924, 2008.

Neale, R. B., Richter, J. H., Conley, A. J., Park, S., Lauritzen, P. H., Gettelman, A., Williamson, D. L., Rasch, P. J., Vavrus, S. J., Taylor, M. A., Collins, W. D., Zhang, M., and Lin, S.-J.: Description of the NCAR Community Atmosphere Model (CAM5.0), NCAR Tech. Rep. NCAR/TN-486+STR, 268 pp., 2010.

Neely, R. R., Toon, O. B., Solomon, S., Vernier, J. P., Alvarez, C., English, J. M., Rosenlof, K. H., Mills, M. J., Bardeen, C. G., Daniel, J. S., and Thayer, J. P.: Recent anthropogenic increases in $\mathrm{SO}_{2}$ from Asia have minimal impact on stratospheric aerosol, Geophys. Res. Lett., 40, 999-1004, doi:10.1002/grl.50263, 2013.

Nightingale, P. D., Malin, G., Law, C. S., Watson, A. J., Liss, P. S., Liddicoat, M. I., Boutin, J., and Upstill-Goddard, R. C.: In situ evaluation of air-sea gas exchange parameterizations using novel conservative and volatile tracers, Global Biogeochem. Cy., 14, 373-387, doi:10.1029/1999GB900091, 2000.

Phang, S.-M., Yeong, H.-Y., Lim, P.-E., Nor, A. R., and Gan, K. T.: Commercial varieties of Kappaphycus and Eucheuma in Malaysia, Malaysian J. Sci., 29, 214-224, 2010.

Pisso, I., Haynes, P. H., and Law, K. S.: Emission location dependent ozone depletion potentials for very short-lived halogenated species, Atmos. Chem. Phys., 10, 12025-12036, doi:10.5194/acp-10-12025-2010, 2010.
Pyle, J. A., Warwick, N., Yang, X., Young, P. J., and Zeng, G.: Climate/chemistry feedbacks and biogenic emissions, Philos. T. R. Soc. A, 365, 1727-1740, doi:10.1098/rsta.2007.2041, 2007.

Quack, B. and Wallace, D.: Air-sea flux of bromoform: Controls, rates, and implications, Global Biogeochem. Cy., 17, 1023, doi:10.1029/2002GB001890, 2003.

Quack, B., Atlas, E., Petrick, G., and Wallace, D. W. R.: Bromoform and dibromomethane above the Mauritanian upwelling: Atmospheric distributions and oceanic emissions, J. Geophys. Res., 112, D09312, doi:10.1029/2006JD007614, 2007.

Ravishankara, A. R., Daniel, J. S., and Portmann, R. W.: Nitrous oxide $\left(\mathrm{N}_{2} \mathrm{O}\right)$ : The dominant ozone-depleting substance emitted in the 21 st century, Science, 326, 123-125, 2009.

Rybka, H. and Tost, H.: Uncertainties in future climate predictions due to convection parameterisations, Atmos. Chem. Phys., 14, 5561-5576, doi:10.5194/acp-14-5561-2014, 2014.

Sala, S., Bönisch, H., Keber, T., Oram, D. E., Mills, G., and Engel, A.: Deriving an atmospheric budget of total organic bromine using airborne in situ measurements from the western Pacific area during SHIVA, Atmos. Chem. Phys., 14, 6903-6923, doi:10.5194/acp-14-6903-2014, 2014.

Salawitch, R. J., Weisenstein, D. K., Kovalenko, L. J., Sioris, C. E., Wennberg, P. O., Chance, K., Ko, M. K. W., and McLinden, C. A.: Sensitivity of ozone to bromine in the lower stratosphere, Geophys. Res. Lett., 32, L05811, doi:10.1029/2004GL021504, 2005.

Schofield, R., Fueglistaler, S., Wohltmann, I., and Rex, M.: Sensitivity of stratospheric Bry to uncertainties in very short lived substance emissions and atmospheric transport, Atmos. Chem. Phys., 11, 1379-1392, doi:10.5194/acp-11-1379-2011, 2011.

Sinnhuber, B.-M., Sheode, N., Sinnhuber, M., Chipperfield, M. P., and Feng, W.: The contribution of anthropogenic bromine emissions to past stratospheric ozone trends: a modelling study, Atmos. Chem. Phys., 9, 2863-2871, doi:10.5194/acp-9-2863-2009, 2009.

Sioris, C. E., Kovalenko, L. J., McLinden, C. A., Salawitch, R. J., Van Roozendael, M., Goutail, F., Dorf, M., Pfeilsticker, K., Chance, K., von Savigny, C., Liu, X., Kurosu, T. P., Pommereau, J.-P., Bösch, H., and Frerick, J.: Latitudinal and vertical distribution of bromine monoxide in the lower stratosphere from Scanning Imaging Absorption Spectrometer for Atmospheric Chartography limb scattering measurements, J. Geophys. Res., 111, D14301, doi:10.1029/2005JD006479, 2006.

Solomon, S., Mills, M., Heidt, L. E., Pollock, W. H., and Tuck, A. F.: On the evaluation of ozone depletion potentials, J. Geophys. Res., 97, 825-842, 1992.

Tang, Q., Zhang, J., and Fang, J.: Shellfish and seaweed mariculture increase atmospheric $\mathrm{CO}_{2}$ absorption by coastal ecosystems, Mar. Ecol.-Prog. Ser., 424, 97-104, 2011.

Taylor, K. E., Stouffer, R. J., and Meehl, G. A.: The CMIP5 experiment design. B. Am. Meteorol. Soc., 93, 485-498, 2012.

Tegtmeier, S., Krüger, K., Quack, B., Atlas, E. L., Pisso, I., Stohl, A., and Yang, X.: Emission and transport of bromocarbons: from the West Pacific ocean into the stratosphere, Atmos. Chem. Phys., 12, 10633-10648, doi:10.5194/acp-12-10633-2012, 2012.

Tilmes, S., Kinnison, D. E., Garcia, R. R., Salawitch, R., Canty, T., Lee-Taylor, J., Madronich, S., and Chance, K.: Impact of very short-lived halogens on stratospheric ozone abundance and UV 
radiation in a geo-engineered atmosphere, Atmos. Chem. Phys., 12, 10945-10955, doi:10.5194/acp-12-10945-2012, 2012.

Velders, G. J. M., Andersen, S. O., Daniel, J. S., Fahey, D. W., and McFarland, M.: The Importance of the Montreal Protocol in Protecting Climate, P. Natl. Acad. Sci., 104, 4814-4819, doi:10.1073/pnas.0610328104, 2007.

Vernier, J. P., Thomason, L. W., Pommereau, J. P., Bourassa, A., Pelon, J., Garnier, A., Hauchecorne, A., Blanot, L., Trepte, C., Degenstein, D., and Vargas, F.: Major influence of tropical volcanic eruptions on the stratospheric aerosol layer during the last decade, Geophys. Res. Lett., 38, L12807, doi:10.1029/2011GL047563, 2011.

Warwick, N. J., Pyle, J. A., Carver, G. D., Yang, X., Savage, N. H., O'Connor, F. M., and Cox, R. A.: Global modeling of biogenic bromocarbons, J. Geophys. Res., 111, D24305, doi:10.1029/2006JD007264, 2006.

Wuebbles, D. J.: Chlorocarbon emission scenarios: Potential impact on stratospheric ozone, J. Geophys. Res., 88, 1433-1443, 1983.

Wuebbles, D. J., Patten, K., Johnson, M., and Kotamarthi, R.: New methodology for ozone depletion potentials of short-lived compounds: n-propyl bromide as an example, J. Geophys. Res., 106, 14551-14571, 2001.
Yang, X., Abraham, N. L., Archibald, A. T., Braesicke, P., Keeble, J., Telford, P. J., Warwick, N. J., and Pyle, J. A.: How sensitive is the recovery of stratospheric ozone to changes in concentrations of very short-lived bromocarbons?, Atmos. Chem. Phys., 14, 10431-10438, doi:10.5194/acp-14-10431-2014, 2014.

Ziska, F., Quack, B., Abrahamsson, K., Archer, S. D., Atlas, E., Bell, T., Butler, J. H., Carpenter, L. J., Jones, C. E., Harris, N. R. P., Hepach, H., Heumann, K. G., Hughes, C., Kuss, J., Krüger, K., Liss, P., Moore, R. M., Orlikowska, A., Raimund, S., Reeves, C. E., Reifenhäuser, W., Robinson, A. D., Schall, C., Tanhua, T., Tegtmeier, S., Turner, S., Wang, L., Wallace, D., Williams, J., Yamamoto, H., Yvon-Lewis, S., and Yokouchi, Y.: Global sea-toair flux climatology for bromoform, dibromomethane and methyl iodide, Atmos. Chem. Phys., 13, 8915-8934, doi:10.5194/acp13-8915-2013, 2013.

Ziska, F., Quack, B., Krüger, K., and Tegtmeier, S.: Future emissions of halocarbons based on CMIP 5 model output fields, Atmos. Chem. Phys. Discuss., in preparation, 2015. 